\title{
Molecular study supports the position of the New Zealand endemic genus Lamellomorpha in the family Vulcanellidae (Porifera, Demospongiae, Tetractinellida), with the description of three new species
}

\author{
Michelle KELLY ${ }^{1, *}$, Paco CÁRDENAS ${ }^{2, *}$, Nicola RUSH ${ }^{3}$, Carina SIM-SMITH ${ }^{4}$, \\ Diana MACPHERSON ${ }^{5}$, Mike PAGE $^{6} \&$ Lori J. BELL ${ }^{7}$ \\ ${ }^{1,3,4}$ Coasts and Oceans National Centre, National Institute of Water and Atmospheric Research, \\ P.O. Box 109-695, Newmarket, Auckland, New Zealand. \\ ${ }^{2}$ Pharmacognosy, Department of Medicinal Chemistry, BioMedical Centre, Husargatan 3, \\ Uppsala University, 75123 Uppsala, Sweden. \\ ${ }^{5}$ Coasts and Oceans National Centre, National Institute of Water and Atmospheric Research, \\ Private Bag 14901, Kilbirnie, Wellington, New Zealand. \\ ${ }^{6}$ Coasts and Oceans National Centre, National Institute of Water and Atmospheric Research, \\ P.O. Box 893, Nelson, New Zealand. \\ ${ }^{7}$ Coral Reef Research Foundation, Box 1765, Koror, 96940 Palau.
}

*Corresponding authors: michelle.kelly@niwa.co.nz ${ }^{1}$,paco.cardenas@ilk.uu.se ${ }^{2}$

${ }^{3}$ Email: Nicola.Rush@niwa.co.nz

[4Email: carina@clearsight.co.nz

${ }^{5}$ Email: Diana.Macpherson@niwa.co.nz

${ }^{6}$ Email: Mike.Page@niwa.co.nz

${ }^{7}$ Email: crrfpalau@gmail.com

\footnotetext{
${ }^{1}$ urn:lsid:zoobank.org:author:F9B821F7-90D0-40C5-8FB3-E96FB0502A4D

${ }^{2}$ urn:1sid:zoobank.org:author:9063C523-49FC-427E-9E84-DBC31C5DB6D3

${ }^{3}$ urn:Isid:zoobank.org:author:D3B1B062-6550-46C0-B562-DDDC42EEE215

${ }^{4}$ urn:1sid:zoobank.org:author:F0205A9D-64B1-4561-8D6B-13429DC01FF3

${ }^{5}$ urn:lsid:zoobank.org:author:106CF6B0-9E37-40BB-A85B-0C08010FFEFB

${ }^{6}$ urn:1sid:zoobank.org:author:75F24D6D-DB93-4CFC-8978-55BE8404BEB3

${ }^{7}$ urn:lsid:zoobank.org:author:4D42296F-6565-4E8F-AEBA-202E240B320C
}

\begin{abstract}
Due to the possession of huge contort strongyles, and a lack of triaenes in an otherwise 'astrophorine' spicule complement, the phylogenetic position of the endemic, monospecific New Zealand sponge genus, Lamellomorpha Bergquist, 1968, has remained enigmatic. The genus was established within Jaspidae de Laubenfels, 1968 (in the abandoned order Epipolasida Sollas, 1888), but it was not until 2002 that the genus was transferred formally to Astrophorina Sollas, 1887, albeit incertae sedis, by Hooper \& Maldonado (2002). In this study, we recognise specimens of Lamellomorpha from the Subantarctic New Zealand region and Chatham Rise, considered by Bergquist to be conspecific with the type species, L. strongylata Bergquist, 1968, first described from the Three Kings-Spirits Bay
\end{abstract}


region of Northland, as the new species, L. australis Kelly \& Cárdenas sp. nov. These two species of Lamellomorpha have differences in external morphology and colour, skeletal architecture and spicules, natural products, geographical distribution, and depth ranges. Sequencing of the COI Folmer barcode/ mini-barcode and of $28 \mathrm{~S}$ (C1-C2 domains) of these two species suggests phylogenetic affinities of Lamellomorpha with the tetractinellid suborder Astrophorina and the family Vulcanellidae Cárdenas et al., 2011. Two Subantarctic New Zealand species of the vulcanellid genus Poecillastra Sollas, 1888, $P$. ducitriaena Kelly \& Cárdenas sp. nov. and P. macquariensis Kelly \& Cárdenas sp. nov., provide further support for the close relationship of Lamellomorpha and Poecillastra.

Keywords. New species, Poecillastra, Porifera, secondary loss, Subantarctic New Zealand.

Kelly M., Cárdenas P., Rush N., Sim-Smith C., MacPherson D., Page M. \& Bell L.J. 2019. Molecular study supports the position of the New Zealand endemic genus Lamellomorpha in the family Vulcanellidae (Porifera, Demospongiae, Tetractinellida), with the description of three new species. European Journal of Taxonomy 506: 1-25. https://doi.org/10.5852/ejt.2019.506

\section{Introduction}

Lamellomorpha strongylata Bergquist, 1968 (class Demospongiae Sollas, 1885, order Tetractinellida Marshall, 1876, suborder Astrophorina Sollas, 1887 incertae sedis) was first described from the Three Kings Islands to the north of New Zealand and recently recollected by the National Institute of Water \& Atmospheric Research (NIWA) and the Coral Reef Research Foundation, Republic of Palau (CRRF) from Middlesex Bank to the north of Three Kings Islands and Spirits Bay on the northern tip of the North Island. In the original description, Bergquist (1968) included two specimens from the Campbell Plateau in the Subantarctic New Zealand region (New Zealand Oceanographic Institute (NZOI) Stations B176 and B184, $84 \mathrm{~m}$ and $188 \mathrm{~m}$ depth, respectively) and considered these to be the same species. While the specimens have not been relocated within the NIWA Invertebrate Collection (NIC), a recent opportunity to examine older material in NIC revealed a surprising number of the 'southern form' of L. strongylata Bergquist, 1968 from Bounty Platform (NZOI Station A751, $155 \mathrm{~m}$ depth), Solander Trough, Campbell Platform, and Macquarie Ridge, all in the Subantarctic New Zealand region, and Mernoo Bank on Chatham Rise, to the east of the South Island. One specimen from the Snares Island Platform was of great interest as it had rare calthrop-like triaenes amongst what appeared to be a spicule complement almost identical to that of $L$. strongylata, suggesting a relationship with calthrop-containing tetractinellid species, such as in families Calthropellidae Lendenfeld, 1907 or Pachastrellidae Carter, 1875.

The systematic position and phylogenetic affinity of Lamellomorpha Bergquist, 1968 has been the subject of some debate since it was first described. Bergquist (1968) established the genus within Jaspidae de Laubenfels, 1968 in the abandoned order Epipolasida Sollas, 1888, based on the possession of exclusively monaxon megascleres with asterose microscleres, i.e., lacking triaenes. Bergquist stated that "L. strongylata would be a typical Jaspis were it not for the completely different microsclere content of microstrongyles and streptasters", which she likened to those in Triptolemma simplex (Sarà, 1959) in the Pachastrellidae.

In 2002, the genus was transferred from Jaspidae to Astrophorina Sollas, 1887 incertae sedis by Hooper \& Maldonado (2002), who explored a plethora of hypotheses on the relationship of Lamellomorpha with Ancorinidae Schmidt, 1870, Pachastrellidae, 'Lithistid demospongiae', Hadromerida Topsent, 1894, and Halichondrida Gray, 1867. Bergquist's initial thoughts were that Lamellomorpha was closely comparable to Coppatias (Ecionemia) baculifera (Kirkpatrick, 1903), due to the joint possession of microstrongyles, and to Jaspis serpentina Wilson, 1925 on the joint possession of microstrongyles and contort oxeas, and 
thus had affinities with species of Jaspis Gray, 1867 and Coppatias Sollas, 1888 (Jaspis) in the current family Ancorinidae. Hooper \& Maldonado (2002) rejected Bergquist's initial hypotheses on the basis that both species possess euaster microscleres (Lamellomorpha has streptasters), a relatively strong synapomorphy for Ancorinidae sensu stricto. Hooper \& Maldonado (2002) also rejected Bergquist's suggestion of possible affinity with Triptolemma simplex, and thus the family Pachastrellidae, because Lamellomorpha lacks the triaene megascleres that are used to judge the affinity with other genera. They also considered any similarity with the form, dimensions and disposition of the megascleres and microscleres to be artificial.

Kelly, in Cryer et al. (2000), tentatively assigned specimens of L. strongylata and 'Lamellomorpha n. sp. 1' (Kelly et al. 2009) to the desma-bearing, lithistid family Theonellidae Lendenfeld, 1903, after discussions with Professor Murray Munro, University of Canterbury, on the potential origins of the secondary metabolite chemistry of the specimens (Dumdei et al. 1997; Li et al. 1998; Hickford 2007): Munro's group identified calyculins, calyculinamides and swinholide H (Dumdei et al. 1997), and cyclic peptolide theonellapeptolide IIIe (Li et al. 1998), compounds which are related to those found in Discodermia calyx Döderlein, 1884 and Theonella swinhoei Gray, 1868 suggesting a broad relationship with the lithistid family Theonellidae. Hooper \& Maldonado (2002) also put forward the suggestion that $L$. strongylata might be a "lithistid demosponge" that has "lost" its desma megascleres. Indeed, several theonellid lithistids are known with only rudimentary desmas (Kelly-Borges et al. 1994: Discodermia dissoluta Schmidt, 1880, in the tropical Western Atlantic) or no desmas at all (Australian species Theonella deliqua Hall et al., 2014 and Theonella maricae Hall et al., 2014). However, the possession of extremely long, contort strongyles, not seen in other lithistids, and a lack of triaenes in L. strongylata precludes this assignment.

Cárdenas et al. (2011) suggested that L. strongylata might be phylogenetically close to Characella Sollas, 1886, or to Pachastrella Schmidt, 1868, based on the possession of small ectosomal monoaxial spicules. Cárdenas et al. (2011) and Cárdenas \& Rapp (2012) concluded that Pachastrellidae sensu Maldonado (2002) was polyphyletic and reorganised the genera possessing streptasters into three families (Pachastrellidae; Theneidae Carter, 1883; Vulcanellidae Cárdenas et al., 2011) and three incertae sedis groups (Lamellomorpha incertae sedis, Characella incertae sedis, Neamphius de Laubenfels, 1953 incertae sedis) within the Astrophorina.

Neither Cárdenas et al. (2011) nor Cárdenas \& Rapp (2012) sampled L. strongylata for molecular sequences. Here, we sequence, for the first time, the COI Folmer barcode/mini-barcode and 28S (C1C2 domains) of L. strongylata and the new species L. australis Kelly \& Cárdenas sp. nov. We also describe a second, less common Subantarctic New Zealand species, initially identified as a third species of Lamellomorpha with rare, calthrop-like triaenes, but now considered to be a species of Poecillastra Sollas, 1888, in the family Vulcanellidae: Poecillastra ducitriaena Kelly \& Cárdenas sp. nov. The systematic and phylogenetic implications of these species are considered with respect to the broader phylogenetic position of Lamellomorpha, Poecillastra, and the wider Tetractinellida.

\section{Material and methods}

\section{Collections and morphological systematics}

Specimens were collected by rock and cone dredges as well as by beam and Agassiz medium trawls, from several research vessels between 1962 and 2010. The majority of specimens were collected onboard the National Institute of Water \& Atmospheric Research (NIWA) research vessels RV Tangaroa and RV Kaharoa; numerical voyage identifier and associated stations cited as NIWA Stn TAN(voyage number)/(station number) and NIWA Station $\mathrm{KAH}($ voyage number)/(station number), respectively. 
Several specimens from the Three Kings Islands were collected by dredge from RV Kaharoa in 1999, on a voyage chartered by the CRRF.

Specimens were frozen immediately upon collection and then preserved in $70 \%$ ethanol or preserved immediately into $70 \%$ ethanol (CRRF). Histological sections of the sponges were prepared by embedding a small piece of the sponge in paraffin wax and then sectioning with a microtome at $70 \mu \mathrm{m}$. Spicule slides and SEM spicule preparations were made following the methods of Kelly \& Sim-Smith (2012). Clean spicules for SEM examination were spread on a plastic disc, air-dried, and coated with platinum for $600 \mathrm{~s}$. Spicules were viewed on a Philips XL30S FEG SEM. Spicule dimensions were measured using a Meji MT5300L compound microscope fitted with a Leica DFC420 microscope camera that was connected to Leica Application Suite imaging software (Leica Microsystems (Switzerland) Ltd.). Spicule measurements in the species descriptions are given as the mean length (range) $\times$ mean width (range) of twenty spicule measurements per specimen unless stated otherwise and are based on measurements from the holotype or paratypes and confirmed through examination of all other specimens. Collection information on specimens examined in this study and previous records were gathered in a table made available in the PANGAEA data repository (https://doi.pangaea.de/10.1594/PANGAEA.895370).

Primary and secondary type material of the new species, and additional material, are accessed within the NIWA Invertebrate Collection (NIC) at NIWA, Greta Point, Wellington, using the prefix 'NIWA-'. Pieces of the holotypes of L. strongylata, L. australis sp. nov., and Poecillastra ducitriaena sp. nov. are also stored at the Zoological Museum in Uppsala, Sweden (prefix 'UPSZTY-').

Additional abbreviations used in the text include CRRF (Coral Reef Research Foundation, Palau). The taxonomic authority for the new taxa described in this paper is restricted to the authors Michelle Kelly and Paco Cárdenas.

\section{Systematics}

General classification and the names of class, order, suborder, and family follow the classification proposal by Morrow \& Cárdenas (2015). The systematics of the family Vulcanellidae follows Cárdenas et al. (2011). Terminology for the streptaster microscleres follows Sollas (1888), as used in Cárdenas \& Rapp (2012): streptasters are categorised as spirasters (small, many actines, twisted, long shaft), metasters (intermediate morphology), plesiasters (large, few actines, short or disappearing shaft), and amphiasters (where actines radiate from both ends of a straight shaft).

\section{Molecular systematics}

DNA was extracted using a DNeasy Blood and Tissue kit (Qiagen). PCRs were carried out in $25 \mu 1$ solutions using PuReTaq Ready-To-Go PCR beads (GE Healthcare). Due to poor preservation of the specimens for molecular work (storage in $70 \%$ ethanol, instead of the recommended $96 \%$ ethanol), the DNA quantities were very low, and it was very degraded (observation on a gel of $1 \mu 1$ of DNA extract). The complete Folmer fragment could not be sequenced using the standard animal barcoding primer pair LCO1490/HCO2198 (Folmer et al. 1994) so it was sequenced in two parts: the universal minibarcode (130 bp, without primers) was obtained using the primer pair LCO1490/Tetract-minibarR1 (Cárdenas \& Moore 2019). Then the second part of the Folmer fragment (539 bp, without primers) was amplified using the primer pair VulcanF2/HCO2198. VulcanCOI-F2 (5'-GGGGATGACCAACTTTATAATG-3') is a new specific primer made to amplify COI in Vulcanellidae species. PCR conditions were $(5 \mathrm{~min} / 94$ ${ }^{\circ} \mathrm{C} ; 37$ cycles $\left.\left(15 \mathrm{~s} / 94{ }^{\circ} \mathrm{C}, 15 \mathrm{~s} / 46{ }^{\circ} \mathrm{C}, 15 \mathrm{~s} / 72{ }^{\circ} \mathrm{C}\right) ; 7 \mathrm{~min} / 72{ }^{\circ} \mathrm{C}\right)$. The $28 \mathrm{~S}$ fragment $(\mathrm{C} 1-\mathrm{C} 2)$ of $308-369$ bp, was obtained using the primer pair $\mathrm{C} 1$ '/Ep3 (Chombard et al. 1998) and the same PCR program as for COI except that we used $50^{\circ} \mathrm{C}$ for the annealing temperature. We pruned the comprehensive Tetractinellida COI alignment from Kelly \& Cárdenas (2016), to keep only species of Astrophorina. We added additional sequences of Astrophorina from the Galapagos (Schuster et al. 2018) along with 
the new sequences. The COI data matrix included 115 sequences (with eight Spirophorina Bergquist \& Hogg, 1969 outgroups). For 28S, we built an alignment based upon the Astrophorina 28S (C1-D2) alignment from Cárdenas et al. (2011) and added Astrophorina 28S (C1-D2) sequences (Thacker et al. 2013; Schuster et al. 2015, 2018). The 28S data matrix included 126 sequences (with seven Spirophorina outgroups) and was automatically aligned using MAFFT v.7 (Katoh \& Standley 2013), L-INS-i option, implemented in AliView 1.18 (Larsson 2014). Phylogenetic analyses were conducted on the CIPRES science gateway v. 3.3 (http://www.phylo.org) (Miller et al. 2010): RAxML 8.2.10 (Stamatakis 2014) for maximum likelihood (ML) and MrBayes v. 3.2.6 (Ronquist et al. 2012) for Bayesian analyses. Bayesian analyses were run with BEAGLE, and consisted of two runs of four chains, each for 5000000 generations and sampled every 1000 tree after a $25 \%$ burn-in.

\section{Results}

Class Demospongiae Sollas, 1885

Order Tetractinellida Marshall, 1876

Suborder Astrophorina Sollas, 1887

Family Vulcanellidae Cárdenas, Xavier, Reveillaud, Schander \& Rapp, 2011

Diagnosis (modified from Cárdenas et al. 2011)

Astrophorina with calthrops, short-shafted triaenes or long-shafted triaenes, in addition to large oxeas and contort or sinuous strongyloxeas. Aster microscleres include several categories of streptasters (spirasters, metasters, amphiasters, and plesiasters). Monaxonic spicules consist of one to three categories of spiny microxeas or microstrongyles.

\section{Lamellomorpha Bergquist, 1968}

Lamellomorpha Bergquist, 1968: 30.

Diagnosis (modified from Hooper \& Maldonado 2002)

Massive, lamellate stalked-palmate, or paddle-shaped sponges, with a relatively smooth, granular, or fleshy, slightly conulose surface. Ectosomal skeleton a skin-like membrane packed with microstrongyles. Choanosomal skeletal architecture a core of megascleres, which are straight, curved, sinuous, or contort oxeas, frequently modified with one or both ends rounded as in strongyloxeas. These radiate through the stalk and fan. Straight oxeas arise as short subectosomal tracts that emerge oblique to the surface. Roughened microstrongyles or microxeas and streptasters (amphiasters, metasters, and spirasters) scattered throughout the body.

\section{Type species}

Lamellomorpha strongylata Bergquist, 1968 (by monotypy).

Lamellomorpha strongylata Bergquist, 1968

Figs 1-2, 6; Tables 1-2

Lamellomorpha strongylata Bergquist, 1968 (in part): 31-32, pls 4a, 11e-f, fig. 10.

Lamellomorpha strongylata - Cryer et al. 2000: 21, appendix 8a-b. - Hooper \& Maldonado 2002:

165-167, fig. 1. - Hickford 2007: 40. — Kelly et al. 2009: 42. — NABIS 2017: 1-4.

'Lamellomorpha n. sp. K \& W' in Cryer et al. 2000: 42 (NIWA 51169 leg.). 


\section{Type material}

\section{Holotype}

NEW ZEALAND • Northeast of Three Kings Islands, NZOI Station B93; $33.983^{\circ} \mathrm{S}, 172.350^{\circ} \mathrm{E}$; depth 54-109 m; 22 Oct. 1958; NIWA 356 (NZOI H-33) leg.; beam trawl; UPSZTY 178600 (a piece of the holotype preserved in $70 \%$ ethanol, as well as a spicule preparation), NIWA.

\section{Other material examined}

NEW ZEALAND - Northeast of Three Kings Islands, NIWA Station Z9678 (KAH9901/27); 34.360 ${ }^{\circ}$, $172.712^{\circ} \mathrm{E}$; depth 48 m; 26 Jan. 1999; NIWA 51169 and 51172 leg.; UPSZMC 178601 (fragment of NIWA 51172 leg. preserved in $70 \%$ ethanol), NIWA • Northeast of Three Kings Islands, NIWA Station Z9686 (KAH9901/43); 34.361 $\mathrm{S}, 172.686^{\circ} \mathrm{E}$; depth 48 m; 27 Jan. 1999; NIWA 51267 leg.; UPSZMC 178603 (fragment preserved in 70\% ethanol), NIWA • Northeast of Three Kings Islands, NIWA Station Z9699 (KAH9901/67); 34.360 S, $172.673^{\circ} \mathrm{E}$; depth 41 m; 28 Jan. 1999; NIWA 51438 leg.; NIWA • Northeast of Three Kings Islands, NIWA Station Z9710 (KAH9901/85); $34.353^{\circ} \mathrm{S}, 172.765^{\circ} \mathrm{E}$; depth 54 m; 28 Jan. 1999; NIWA 51582 leg.; dredge; NIWA • Three Kings Islands, $2.5 \mathrm{~nm}$ east of Great Island, NIWA Station Z15944; 34.170 S, 172.210 E; depth 200 m; 16 Apr. 1999; CRRF, NIWA 93474 leg.; dredge; NIWA • Spirits Bay, Northland, NIWA Station KAH0606/D3; 34.36 S, $172.847^{\circ}$ E; 15

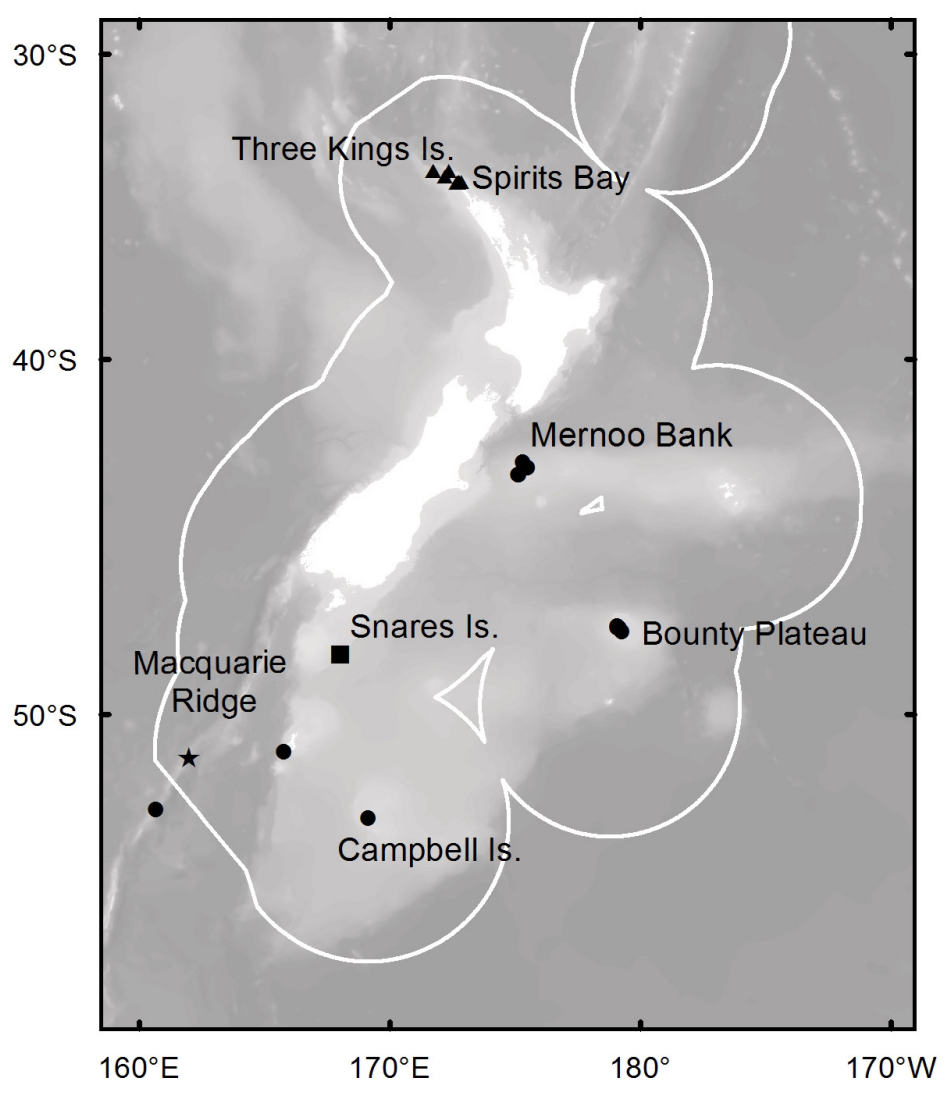

Fig. 1. Study area showing the collection localities for: Lamellomorpha strongylata Bergquist, 1968, around Middlesex Bank, Three Kings Islands, and Spirits Bay (triangles); L. australis Kelly \& Cárdenas sp. nov., Bounty Platform, Campbell Plateau, Solander Trough, and Macquarie Ridge (Australian EEZ) (circles); Poecillastra ducitriaena Kelly \& Cárdenas sp. nov., on the eastern edge of the Snares Platform (square); and Poecillastra macquariensis Kelly \& Cárdenas sp. nov., on Seamount 5, Macquarie Ridge (star). 


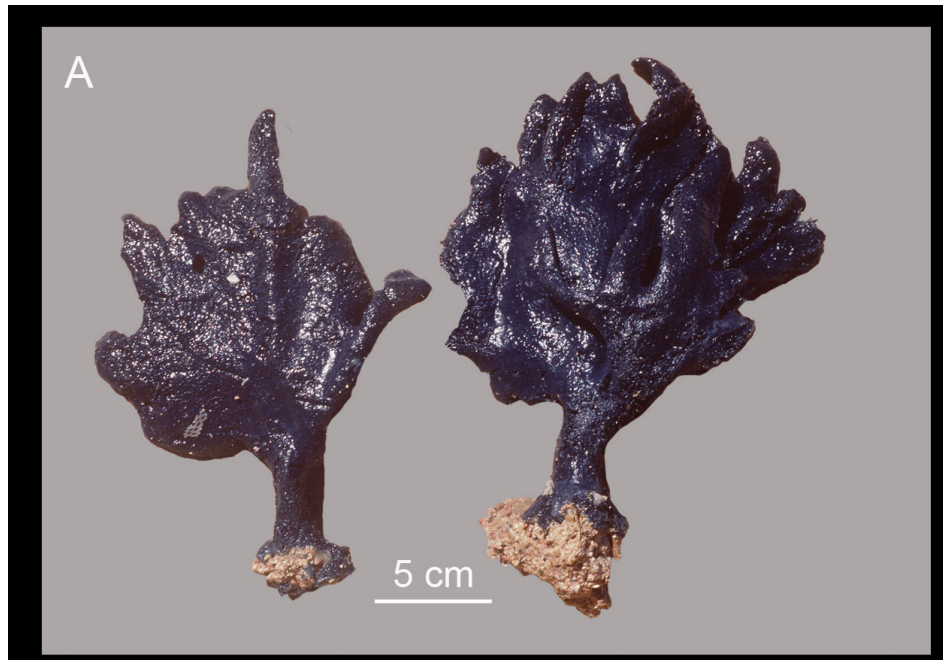

\section{B}
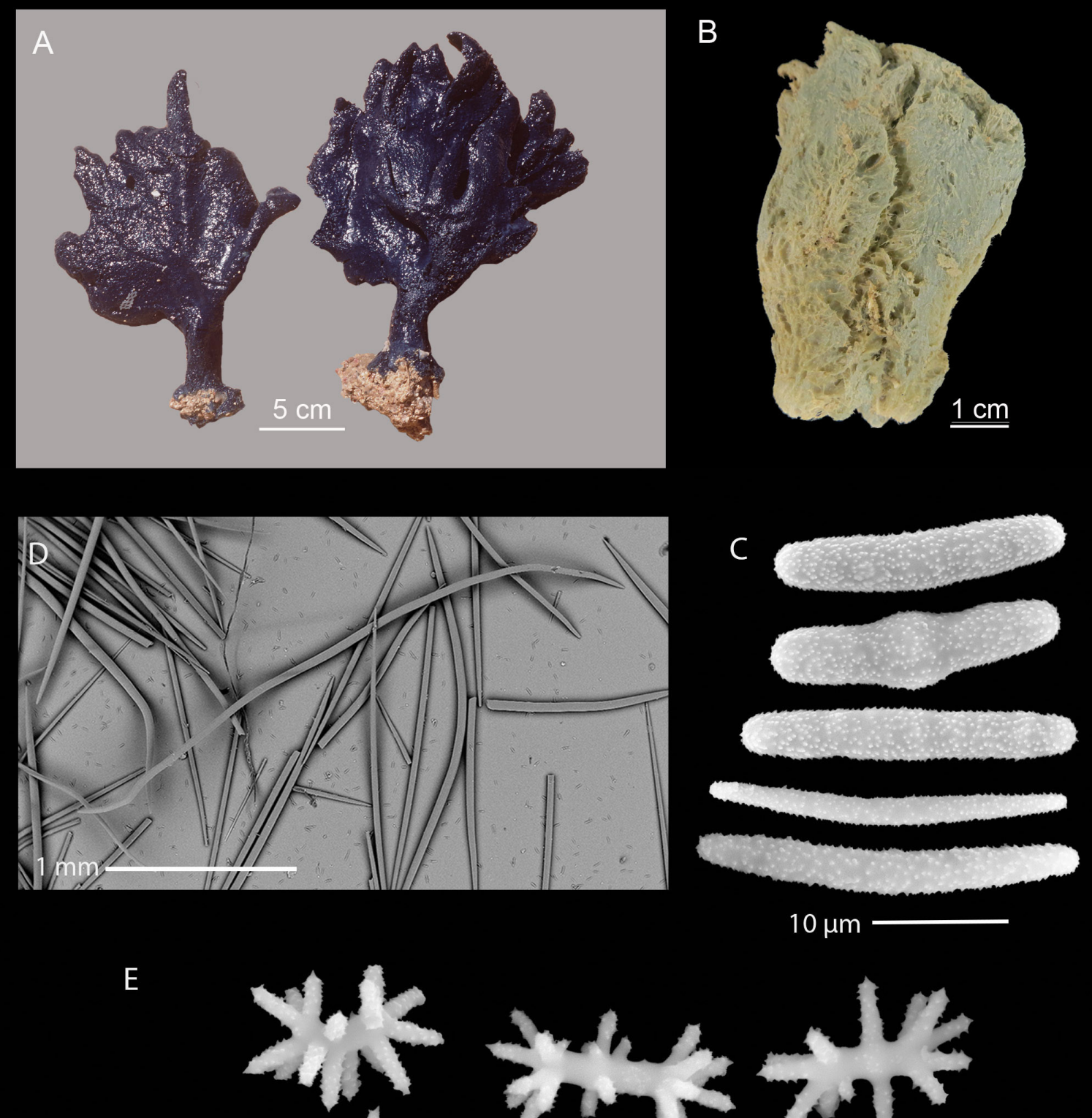

$\mathrm{F}$
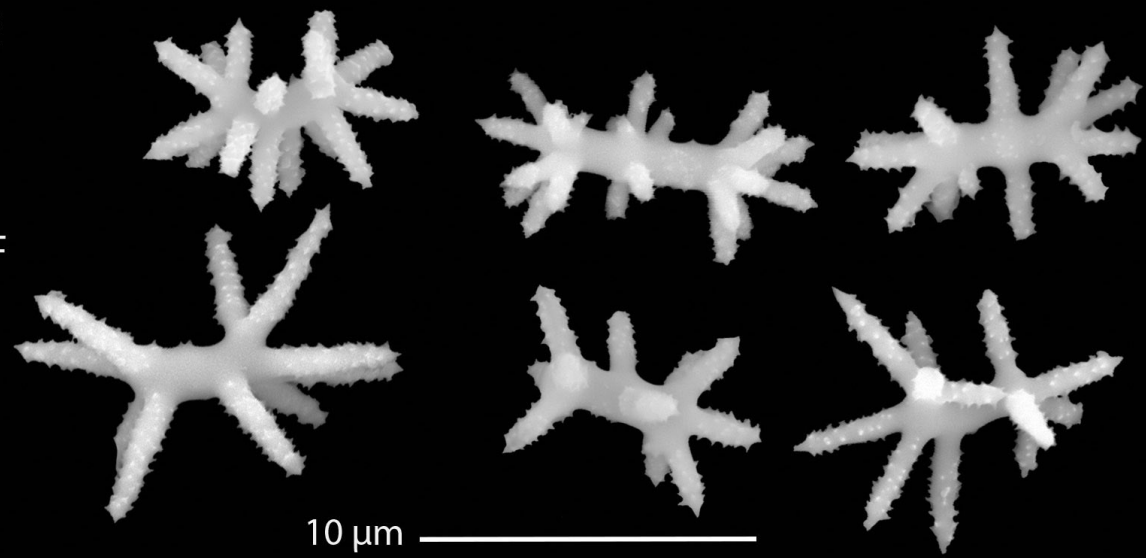

Fig. 2. Morphology, megascleres and microscleres of Lamellomorpha strongylata Bergquist, 1968. A. Deck image showing midnight blue colouration and palmate morphology (NIWA 93474 leg., image Lori J. Bell, CRRF). B. Loss of colouration and radiating skeleton (NIWA 73253 leg.). C. Range of roughened microstrongyles showing centrotylote forms and more typical curved forms (penultimate: NIWA 356 leg., rest: NIWA 93474 leg.). D. Sinuous oxeas (NIWA 93474 leg.). E. Metaster- to amphiaster-like streptasters (left: NIWA 93474 leg., center and right: NIWA 356 leg.); F. Metaster- to amphiaster-like streptasters (left and center: NIWA 356 leg., right: NIWA 93474 leg.). 
Table 1. Megascleres and dimensions $(\mu \mathrm{m})$ of Lamellomorpha strongylata Bergquist, 1968 and L. australis Kelly \& Cárdenas sp. nov., given as length [mean (min.--max.)] $\times$ width [mean (min.max.)], $\mathrm{n}=10-17$ unless stated otherwise.

\begin{tabular}{|c|c|c|}
\hline Specimen & Straight megascleres & Contort megascleres \\
\hline \multicolumn{3}{|l|}{ L. strongylata } \\
\hline NZOI Holotype 33 (Bergquist 1968) & $1980(1000-2808) \times 26(14-33)$ & \\
\hline NIWA 00356 (NZOI Holotype 33) & $1993(1520-2416) \times 27(21-31)$ & $1556(1306-1787) \times 17(11-24)$ \\
\hline NIWA 93474 & $1968(1373-2552) \times 22(9-30)$ & $1564(1288-1816) \times 15(8-21)$ \\
\hline \multicolumn{3}{|l|}{ L. australis sp. nov. } \\
\hline NZOI Station B176 (Bergquist 1968) & $1482(1161-1937) \times 23(17-28)$ & \\
\hline NIWA 89736 leg. (holotype) & $1655(1130-1981) \times 26(17-41)$ & not present \\
\hline NIWA 93483 leg. (paratype) & $1754(1454-2223) \times 26(15-36)$ & $2159(1499-3079) \times 25(14-31)$ \\
\hline NIWA 93484 leg. (paratype) & $1562(1403-1988) \times 21(13-27)$ & $2657(2243-3058) \times 23(17-33)$ \\
\hline NIWA 93485 leg. (paratype) & $1640(1044-2026) \times 19(6-25)$ & $3164(2672-3555) \times 23(18-27)$ \\
\hline NIWA 93486 leg. (paratype) & $1725(1231-2320) \times 19(13-28)$ & $2257(1702-3575) \times 20(13-32)$ \\
\hline NIWA 93487 leg. (paratype) & $1752(1226-2613) \times 24(16-31)$ & $2195(1658-3560) \times 23(17-34)$ \\
\hline NIWA 93499 leg. & $1882(1572-2400) \times 27(21-39)$ & $2664(2098-3100) \times 25(16-35)$ \\
\hline
\end{tabular}

May 2005; NIWA 52375 leg.; dredge; NIWA. • Middlesex Bank, Three Kings Rise, NIWA Station TAN1105/43; 33.988 $\mathrm{S}, 171.751^{\circ} \mathrm{E}$; depth 170-174 m; 28 Mar. 2011; NIWA 73243, 73253 leg.; beam trawl; NIWA • Western Continental Slope, Northland, NZOI Station J954 (I808); $34.633^{\circ} \mathrm{S}, 172.225^{\circ}$ E; depth 204-192 m; 18 Jun. 1981; collected by rock dredge; specimen now lost, donated by Dame P. R. Bergquist to Dr P. Karuso, Macquarie University, Sydney.

\section{Description}

The holotype was described by Bergquist (1968) as a "massive, thick, sometimes folded and incurved lamellate sponge", $130 \mathrm{~mm}$ high, $102 \mathrm{~mm}$ wide, and 18-22 mm thick, supported by a stout stalk $30 \mathrm{~mm}$ in diameter. The surface was described as smooth where the dermal membrane was intact, otherwise ragged due to projecting clumps of oxeas and strongyles. Oscules, 1-2.6 $\mathrm{mm}$ in diameter, were found on the convex surface of the lamella and lie flush with the surface (Bergquist 1968). Examination of the numerous preserved specimens in NIC reveal occasional membranous oscules, but it is difficult to tell whether they are restricted to one side of the sponge. However, in the holotype, pores were observed on the opposite side to the oscules, in cribriporal areas, separated by small ridges, or with no boundaries, making a continuous pore surface; each pore is $40-80 \mu \mathrm{m}$ in diameter. The texture was described as, "firm but compressible, crisp, easily broken". The colour in life was described as "bright green" and the colour in spirit, "blue green or yellowish green" (Bergquist 1968). The most recent collection was by the Coral Reef Research Foundation in 1999 (NIWA 93474 leg.; Fig. 2A), who described a "dark, royal blue (not navy blue), (palmate) fan sponge with pointed tips, $20 \mathrm{~cm}$ high and about $1 \mathrm{~cm}$ thick, that tears easily, and which has a fleshy surface".

\section{Skeleton}

The description by Bergquist (1968) of the choanosome as "lax and confused with slight traces of radiate construction discernible", is accurate, but in NIWA 93474 leg. the contort strongyles strongly radiate through the plane of the fan. Bergquist described a "subectosomal region", in which there were tracts of megascleres, variable in thickness, that curved outward and intersect with the surface at an acute angle; in NIWA 93474 leg. these are predominantly oxeas (Fig. 6A). The ectosome is densely packed with microstrongyles and streptasters, which also occur throughout the sponge, but in much less abundance. 
Table 2. Microscleres and dimensions $(\mu \mathrm{m})$ of Lamellomorpha strongylata Bergquist, 1968 and L. australis Kelly \& Cárdenas sp. nov., given as length [mean (min.--max.)] $\times$ width [mean (min.max.)], $\mathrm{n}=10-17$ unless stated otherwise.

\begin{tabular}{lccc}
\hline Specimen & Microstrongyles & Streptasters & Spirasters \\
\hline L. strongylata Bergquist, 1968 & & & \\
\hline NZOI Holotype 33 (Bergquist 1968) & $25(23-28) \times 3(2-4)$ & $10(8-11)$ & not present \\
NIWA 00356 (NZOI Holotype 33) & $23(21-28) \times 3(2-4)$ & $10(8-15)$ & not present \\
NIWA 93474 & $27(24-34) \times 2(2-3)$ & $9(7-12)$ & not present \\
\hline L. australis sp. nov. & & & \\
\hline NZOI Station B176 (Bergquist 1968) & $27(24-30) \times 3(2-4)$ & $10(8-11)$ & not given \\
NIWA 89736 leg. (holotype) & $37(31-42) \times 3(2-4)$ & $12(10-13)$ & $10(8-11)$ \\
NIWA 93483 leg. (paratype) & $32(25-41) \times 2(2-4)$ & $10(8-12)$ & $10(9-15)$ \\
NIWA 93484 leg. (paratype) & $32(29-37) \times 2(1-3)$ & $8(8-9)$ & $10(8-12)$ \\
NIWA 93485 leg. (paratype) & $28(21-38) \times 3(2-5)$ & $10(9-12)$ & $11(9-14)$ \\
NIWA 93486 leg. (paratype) & $36(31-40) \times 2(2-3)$ & $9(7-11)$ & $11(9-13)$ \\
NIWA 93487 leg. (paratype) & $27(19-34) \times 3(1-5)$ & $9(8-12)$ & $10(8-14)$ \\
NIWA 93499 leg. & $32(26-41) \times 2(1-2)$ & $9(8-15)$ & $10(8-12)$ \\
\hline
\end{tabular}

\section{Spicules}

Megascleres (Table 1; Fig. 2D)

Bergquist (1968) considered the megascleres of L. strongylata (Bergquist 1968: 31, 32 (table of spicule dimensions)) to be "strongyles, oxeas and strongyloxeas", all of similar range in length and width, varying only in relative frequency in the two specimens (presumably the Three Kings holotype and the NZOI Station B176 specimen from Campbell Plateau), with oxeas being dominant in the latter. Re-examination of the holotype megascleres, and those of more recent collections, indicate that there are probably two forms of megascleres: 1) straight to slightly curved oxeas that are common in the subectosomal tracts, ranging from about 1500-1750 $\mu \mathrm{m}$ long and up to $25 \mu \mathrm{m}$ thick; and 2) massive sinuous or contort oxeas that are usually very thick and frequently modified with one or both ends rounded as in strongyloxeas, rarely as in true strongyles, ranging from about 1600-2375 $\mu \mathrm{m}$ long and up to $40 \mu \mathrm{m}$ thick. However, it is difficult to distinguish the various megascleres in some specimens, and in some the spicules are much less contort.

Microscleres (Table 2; Fig. 2C-F)

Microstrongyles are "squat, evenly rounded spicules, slightly roughened and occasionally centrotylote" (Bergquist 1968: 31, 32 (table of spicule dimensions)) and range from about 21-34 $\mu \mathrm{m}$ long (Table 2). Bergquist described the streptaster microscleres of L. strongylata (Bergquist 1968: 31, 32 (table of spicule dimensions)) as "plesiasters, small spicules with 3-12 smooth, sharply pointed rays". A reexamination of the holotype (Fig. 2E-F) using scanning electron microscopy has revealed that the streptaster microscleres are metasters and occasionally amphiasters with relatively long microspined rays, all in one size category, following the definition of Sollas (1888), and as used in Cárdenas \& Rapp (2012). We describe these spicules as metaster- to amphiaster-like streptasters with heavily spined, relatively long rays in one size category, ranging in length from about 7-15 $\mu \mathrm{m}$ long (Table 2).

\section{Distribution}

Northeast of New Zealand.

\section{Substrate, depth range and ecology}

Attached to rocky reefs and sediment and rubble-covered rocky platforms, depth 41-200 m. 


\section{DNA barcodes}

COI. NIWA 51172 leg. (minibarcode, MK033624) and NIWA 51267 leg. (MK033623): no bp differences. 28S (C1-C2). NIWA 51172 leg. (MK033143) and NIWA 51267 leg. (MK033142): no bp differences. We failed to get sequences from the holotype.

\section{Remarks}

Lamellomorpha strongylata was originally described in considerable detail by Bergquist (1968), and the holotype was redescribed without re-examination more recently by Hooper \& Maldonado (2002). No further material was examined. Here, for the first time, we illustrate the sponge as it appears upon collection, showing the beautiful royal blue colouration (Fig. 2A), and illustrate the detail and ornamentation of the microscleres (Fig. 2C-F) using scanning electron microscopy. There is little to add to the original description, consequently the description and skeletal details are provided in comparative prose. Lamellomorpha strongylata is restricted to the northernmost tip of New Zealand and beyond to the Three Kings Rise, and is easily recognised in the field by the palmate, tree-like shape and the deep blue to green colouration.

Lamellomorpha australis Kelly \& Cárdenas sp. nov. urn:lsid:zoobank.org:act:2A7459B3-0FBA-441B-806C-7C988075843A

Figs 1, 3, 6; Tables 1-2

Lamellomorpha strongylata - Bergquist 1968: 31-32, pl. 11f (in part). - Dumdei et al. 1997: 26362639. — Li et al. 1998: 724-728. — Hickford 2007: 29-41. — Blunt \& Munro 2008: 285, 1798, 1854. — Buckingham et al. 2010: 349. — Bycroft \& Payne 2013: 429, 1642.

\section{Etymology}

Named for the Chatham Rise and Subantarctic New Zealand distribution of this species ('australis', south, Latin).

\section{Type material}

\section{Holotype}

NEW ZEALAND - Subantarctic region of New Zealand, Bounty Platform, NZOI Station A751; $47.743^{\circ} \mathrm{S}, 179.124^{\circ} \mathrm{E}$; depth 155 m; 16 Nov. 1962; NIWA 89736 leg.; Agassiz medium trawl; UPSZTY 178605 (a small piece of the holotype preserved in 70\% ethanol, as well as a spicule preparation), NIWA.

\section{Paratypes}

NEW ZEALAND - same collection data as for the holotype; NIWA 92896 to 92900, 93483, 93484, and 93487 leg.; NIWA • same collection data as for preceding; NIWA 93485 leg.; UPSZTY 178606 (a small piece of the paratype preserved in $70 \%$ ethanol), NIWA - same collection data as for preceding; NIWA 93486 leg.; UPSZTY 178607 (a small piece of the paratype preserved in 70\% ethanol), NIWA.

\section{Type locality}

Subantarctic region of New Zealand, Bounty Platform; depth 155 m.

\section{Other material examined}

NEW ZEALAND • Bounty Platform, NZOI Station I711; 47.833 ${ }^{\circ}$ S, $179.250^{\circ}$ E; depth $139 \mathrm{~m} ; 22$ Mar. 1979; NIWA 89717 leg.; rock dredge; NIWA • Bounty Platform, NZOI Station A714; $47.725^{\circ}$ S, $179.067^{\circ}$ E; depth 165 m; 5 Nov. 1962; NIWA 86733 leg.; cone and mesh dredge; NIWA • Bounty Platform, NZOI Station A715; 47.683 S, 179.051 E; depth 121 m; 5 Nov. 1962; NIWA 89720 leg.; 


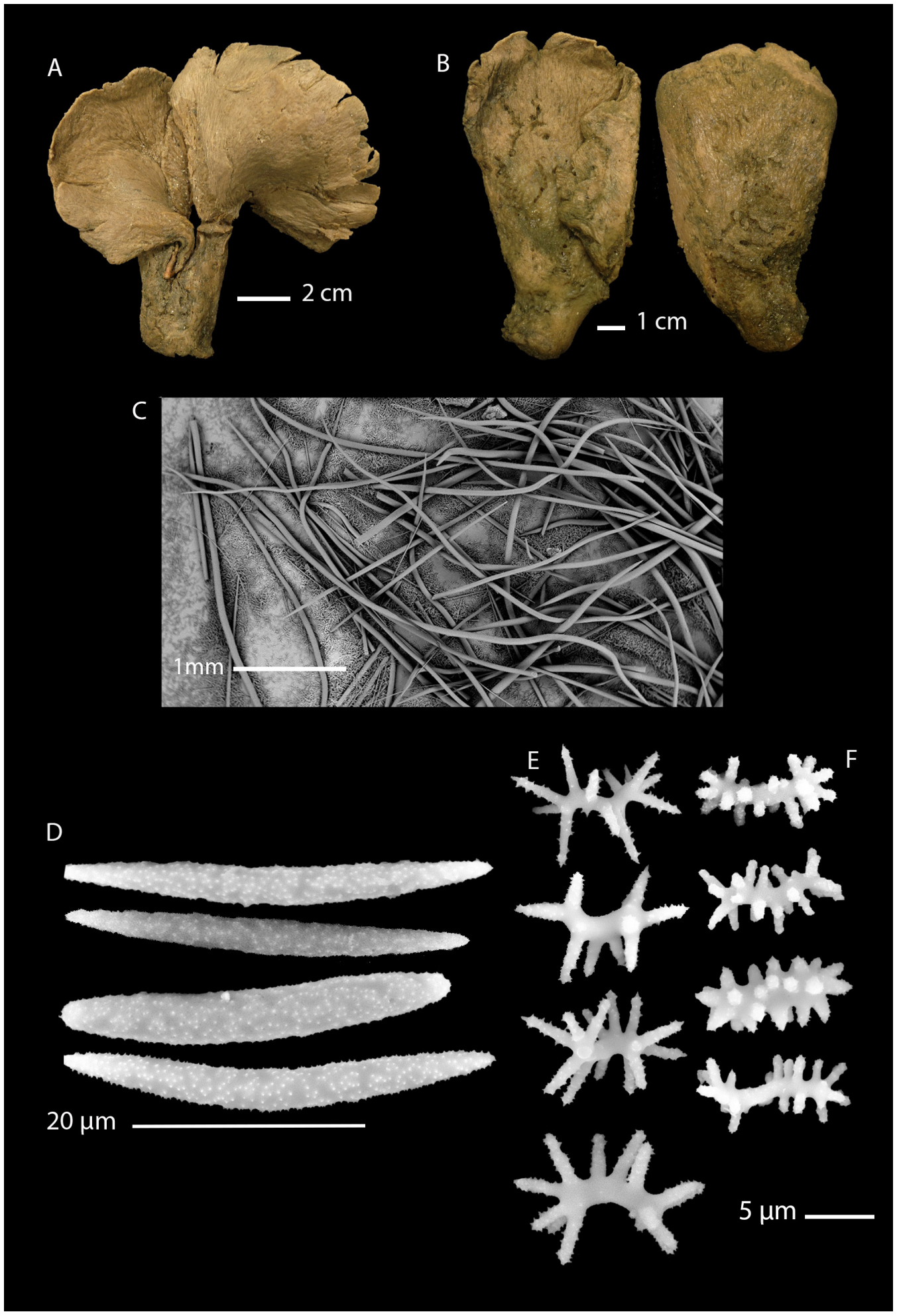

Fig. 3. Morphology, megascleres, and microscleres of Lamellomorpha australis Kelly \& Cárdenas sp. nov. A. Bilamellate form (NIWA 89736 leg., holotype). B. Club-shaped morphology showing both sides (NIWA 93483 leg., paratype). C. Sinuous oxeas (NIWA 44388 leg.). D. Curved, roughened microstrongyles (rounded ends) and microxeas (blunt-pointed ends) (NIWA 44388 leg.). E. Metasterlike streptasters with heavily spined, relatively long rays (NIWA 89736 leg. and NIWA 89717 leg.). F. Spirasters with dense, short, microspined rays (NIWA 44388 leg. and NIWA 89736 leg.). 
cone and mesh dredge; NIWA - Bounty Platform, NZOI Station A757; $47.693^{\circ} \mathrm{S}, 179.058^{\circ} \mathrm{E} ; 17$ Nov. 1962; NIWA 113894 leg.; NIWA • Solander Trough, NZOI Station D39; 50.967 ${ }^{\circ}$ S, $165.750^{\circ}$ E; depth 549 m; 7 May 1963; NIWA 44388 leg.; gear dredge, cone mesh with bag; NIWA • Campbell Platform, NZOI Station B184; 52.615 $\mathrm{S}, 169.117^{\circ} \mathrm{E}$, depth 344 m; 11 Oct. 1959; NIWA 93499 leg.; dredge; NIWA • Macquarie Ridge, NIWA Station TAN0803/69; 52.398 S, $160.657^{\circ}$ E; depth 451-438 m; 9 Apr. 2008; NIWA 40328 leg.; epibenthic sled; NIWA • Chatham Rise, North Mernoo Bank, NIWA Station W427; 43.077 ${ }^{\circ} \mathrm{S}, 175.272^{\circ} \mathrm{E}$; depth 180-237 m; 20 Feb 1995; NIWA 44240 leg.; Agassiz Trawl; NIWA - Chatham Rise, North Mernoo Bank, NIWA Station W446; 43.245 ${ }^{\circ} \mathrm{S}, 175.444^{\circ} \mathrm{E}$; depth 71-76 m; 22 Feb 1995; NIWA 44261 leg.; rock dredge; NIWA • Chatham Rise, North Mernoo Bank, NIWA Station W447; 43.245 ${ }^{\circ} \mathrm{S}, 175.458^{\circ} \mathrm{E}$; depth 80-85 m; 22 Feb 1995; NIWA 44263 leg.; rock dredge; NIWA - Chatham Rise, North Mernoo Bank, NIWA Station W448; $43.240^{\circ} \mathrm{S}, 175.458^{\circ} \mathrm{E}$; depth $74 \mathrm{~m} ; 22$ Feb 1995; NIWA 44267 leg.; rock dredge; NIWA • Chatham Rise, North Mernoo Bank, NIWA Station W446; 43.247 $\mathrm{S}, 175.444^{\circ} \mathrm{E}$; depth 71-76 m; 22 Feb 1995; NIWA 44272 leg.; rock dredge; NIWA • Chatham Rise, North Mernoo Bank, NIWA Station W435; 43.172 ${ }^{\circ}$ S, $175.340^{\circ}$ E; depth 108-113 m; 20 Feb 1995; NIWA 137202 leg.; rock dredge; NIWA • Chatham Rise, North Mernoo Bank, NIWA Station W446; 43.247 ${ }^{\circ}$ S, $175.444^{\circ} \mathrm{E}$; depth 71-76 m; 22 Feb 1995; NIWA 137201 leg.; rock dredge; NIWA • Chatham Rise, South Mernoo Bank, NIWA Station W452; 43.450 ${ }^{\circ} \mathrm{S}, 175.135^{\circ} \mathrm{E}$; depth 120-180 m; 22 Feb 1995; NIWA 44241 leg.; rock dredge; NIWA • Chatham Rise, South Mernoo Bank, NIWA Station W454; 43.451 ${ }^{\circ} \mathrm{S}, 175.109^{\circ} \mathrm{E}$; depth 126-130 m; 22 Feb 1995; NIWA 44262 leg.; rock dredge; NIWA.

\section{Description}

Uni- to bilamellate fan sponge, table tennis bat-shaped (Fig. 3A) or club-shaped (Fig. 3B), 130-200 mm high with a short, broad stalk, 2-3 cm thick, and a relatively thick lamella (up to $2 \mathrm{~cm}$ thick in places), attenuating towards the margins, which are frequently incised. The specimen from NZOI Station B176 was described by Bergquist (1968) as being $160 \mathrm{~mm}$ high, $89 \mathrm{~mm}$ wide, and 32-58 mm thick, supported by a stalk that was broken and thus was not measured. Oscules were not visible in the holotype or any other specimen. Pores are inconspicuous and compressed (probably due to the fixation) and were 40$80 \mu \mathrm{m}$ in diameter (measured on the holotype). Surface relatively smooth with low ridges radiating from the stalk to the fan margins. Texture, relatively soft, compressible. Colour in life and preservative, tan.

\section{Skeleton}

Choanosome disorganised, with megascleres orientated more or less parallel with the axis of the fan and stalk (Fig. 6B-D), with single or a couple of megascleres extending beyond the surface from the subectosome. The ectosome is extremely thick and packed with microstrongyles and streptasters, which also occur in great density throughout the sponge.

\section{Spicules}

Megascleres (Table 1; Fig. 3C)

Bergquist (1968) considered the megascleres of the "subantarctic specimen" (presumably the NZOI Station B176 specimen from Campbell Plateau) to have, "predominantly oxeas, some of which are curved, but most are contort". Our examination of new material reveals that oxeas dominate the megasclere complement; these are rarely to never modified; all have sharp attenuated tips. The majority are straight to slightly curved and contort, but not to the degree seen in L. strongylata. The megascleres reach their greatest length in $L$. australis sp. nov., up to $3575 \mu \mathrm{m}$ long in the specimen NIWA 93486 leg. (paratype).

Microscleres (Table 2; Fig. 3D-F)

Bergquist did not differentiate between the microscleres of the holotype of L. strongylata (from the Three Kings) and the subantarctic Campbell Plateau specimens (L. australis sp. nov.), calling them all "plesiasters" in the table of spicule dimensions. However, in pl. 11, figs E2 and F2-3, a clear difference is 
obvious between the illustrations of the streptasters: they are metasters in p1. 11, fig. E2 (L. strongylata) and larger metasters (pl. 11, fig. F3) and "abnormal microrhabds" in pl. 11, fig. F2 (L. australis sp. nov.). The "abnormal microrhabds" of Bergquist (1968: pl. 11, fig. F2) are most likely spirasters (as in our Fig. 3F), the ornamentation of which would not have been visible under light microscopy available at the time.

Thus, L. australis sp. nov. has three forms of microsclere: a microxea (Fig. 3D) with attenuating, hastate ends that is usually straight, but may be slightly curved, ranging in length from about $19-40 \mu \mathrm{m}$; metaster-like streptasters with heavily spined, relatively long rays (Fig. 3E), ranging in length from about 7-15 $\mu \mathrm{m}$; spirasters with abundant, short, microspined rays that emanate from a long, spiral axis (Fig. 3F), ranging in length from about $8-14 \mu \mathrm{m}$.

\section{Distribution}

Subantarctic region of New Zealand: Mernoo Bank (depth 71-237 m), north-western Chatham Rise (Dumdei et al. 1997; Li et al. 1998); Bounty Platform (depth 121-165 m), Solander Trough (depth 549 m), Campbell Platform (depth 344 m), and Macquarie Ridge (depth 451-438 m).

\section{Substrate, depth range and ecology}

Attached by a thick stalk to sediment covered rocky substrate, depth 71-549 m.

\section{DNA barcodes}

COI. Holotype (minibarcode, MK033625), no bp differences with the COI minibarcode of L. strongylata.

\section{Remarks}

Bergquist (1968) listed two specimens from Campbell Plateau in the Subantarctic region of New Zealand, from NZOI Station B176 $(46$ fathoms $=84.12 \mathrm{~m})$ and NZOI Station B184 $(103$ fathoms $=188.4 \mathrm{~m})$. Unfortunately, neither specimen was found in the NIWA collections and both are presumed lost. However, we did find a specimen from NZOI Station B184 (NIWA 93499 leg.) from a depth of $344 \mathrm{~m}$. Bergquist (1968) considered the two specimens she examined to be conspecific with $L$. strongylata, despite the obvious disjunct distribution, but noted that the subantarctic specimens had predominantly oxeas, an observation we agree with.

Examination of numerous specimens uncovered in NIC allows us to convincingly separate L. australis sp. nov. from the type species on geographic distribution, morphology, and skeletal details, despite the COI minibarcodes not differentiating them (Fig. 7). The most obvious difference that separates L. australis sp. nov. from $L$. strongylata is the markedly disjunct distribution and depth ranges: L. strongylata has only been recorded to the north of New Zealand, 41-200 m depth, while L. australis sp. nov. is only found on and south of Mernoo Bank on the Chatham Rise, ranging in depth from $71 \mathrm{~m}$ on Mernoo Bank, to $549 \mathrm{~m}$ in the Solander Trough. In terms of morphology and colouration in life, L. strongylata forms a relatively soft, dark royal blue, palmate sponge, supported by a relatively narrow stalk, while L. australis sp. nov. forms a distinctive, tan, paddle-shaped sponge, with thin, incised margins, on a thick, short stalk. In terms of skeletal architecture, the choanosome of L. australis sp. nov. is much more densely packed with microscleres than L. strongylata, and the former species lacks the relatively distinct subectosomal tracts of the latter. As noted by Bergquist (1968), the megascleres of L. australis sp. nov. differ from those of $L$. strongylata in being predominantly oxeas (straight and contort) with no modifications of the tips to strongyloxeas as in L. strongylata. In addition, we note that the contort forms are much longer on average, and have a greater size range, than in L. strongylata. Finally, microscleres also discriminate $L$. australis sp. nov. from L. strongylata. Lamellomorpha strongylata has stubby, often centrotylote roughened microstrongyle, while $L$. australis sp. nov. has a relatively fine, curved, slightly 
longer roughened microxea. Lamellomorpha strongylata has metaster- to amphiaster-like streptasters with heavily spined, relatively long rays in one size category, while L. australis sp. nov. has metaster-like streptasters with heavily spined, relatively long rays and spirasters with abundant, short, microspined rays that emanate from a long, spiral axis. Spirasters are absent in L. strongylata.

As part of their ongoing investigations into New Zealand marine natural products in sponges, professors Murray Munro and John Blunt and their group in the Department of Chemistry, University of Canterbury, Christchurch, collected what was identified by the late professor Patricia Bergquist as L. strongylata, from Mernoo Bank on the Chatham Rise. Vouchers of these sponge specimens were donated to NIC for their preservation and future study and have been re-identified here as L. australis sp. nov., extending the known distribution of L. australis sp. nov. north to the Chatham Rise. Thus, it is L. australis sp. nov., and not $L$. strongylata, from which biologically active secondary metabolites were isolated by the University of Canterbury group, including calyculins (A, B, E, and F), calyculinamides (A and B), swinholide H (Dumdei et al. 1997), and theonellapeptolides (Li et al. 1998; Hickford 2007); identical and related compounds are found in sponges in the genus Theonella Gray, 1868 and Discodermia du Bocage, 1869 (family Theonellidae).

It has been shown that calyculins and its derivatives (e.g., calyculinamides) could be produced by the filamentous bacteria 'Entotheonella' spp. in Discodermia (Wakimoto et al. 2014). 'Entotheonella' spp. are especially abundant in Theonella swinhoei, as well as in many other demosponges (Wilson et al. 2014). In her PhD thesis, Hickford (2007) noticed that filamentous heterotrophic (Gram positive) bacteria were very abundant in $L$. australis sp. nov. and were associated with several theonellapeptolides. The producer of theonellapeptolides is currently unknown but the results of Hickford (2007) suggest that $L$. australis sp. nov. may be a host for theonellapeptolides-producing 'Entotheonella'-like bacteria. Hickford (2007) also isolated unicellular bacteria from the same specimens and showed these were associated with swinholide H. This result concurs with previous results from Bewley et al. (1996), who identified swinholide A in unicellular bacteria isolates from Theonella swinhoei from Palau. However, it is an apparent contradiction with Ueoka et al. (2015) who convincingly show that misakinolide A (swinholide-like compound) from another Theonella swinhoei chemotype (chemotype WA from Japan) is produced by 'Entotheonella serta'. Therefore it seems that swinholide-type compounds may be produced by bacteria other than 'Entotheonella' in L. australis sp. nov. and Theonella swinhoei (chemotype Palau). Hickford (2007) further states that specimens from the "northern population of L. strongylata" (L. strongylata) not only had very low quantities of filamentous bacteria (apparently limited to the surface of the sponge), but also missed the biological activity, and therefore may not produce the above mentioned compounds. Thus, to conclude, L. strongylata and L. australis sp. nov. also clearly differ in terms of natural products and microbial communities.

Poecillastra Sollas, 1888

Poecillastra Sollas, 1888: 105.

Diagnosis (Cárdenas et al. 2011)

Vulcanellidae with spiny microxeas in a single category, triaenes are pseudocalthrops or short-shafted triaenes.

\section{Type species}

Poecillastra compressa (Bowerbank, 1866: 55) (by original designation). 
Poecillastra ducitriaena Kelly \& Cárdenas sp. nov. urn:1sid:zoobank.org:act:E3C570FA-832A-4FDB-97D3-5CDA250A3797

Figs 1, 4, 6

\section{Etymology}

Named for the possession of triaenes in addition to the apparent spiculation of Lamellomorpha, and their guide to the phylogenetic origins of this species ('duci-' in the sense of a guide).

\section{Type material}

\section{Holotype}

NEW ZEALAND - Subantarctic region of New Zealand, east of Snares Island Platform, NIWA Station TRIP3072/8; 48.5 ${ }^{\circ} \mathrm{S}, 168.0^{\circ} \mathrm{E}$; depth 125-213 m; 21 Oct. 2010; NIWA 61944 leg.; fish bottom trawl; UPSZTY 178604 (a small piece of the holotype preserved in 70\% ethanol, as well as a spicule preparation), NIWA.

\section{Type locality}

Subantarctic region of New Zealand, Snares Island Platform, depth 125-213 m.

\section{Description}

Multilamellate, foliose, fan sponge (Fig. 4A), $160 \mathrm{~mm}$ high, $104 \mathrm{~mm}$ wide, with a short thick stalk about $2 \mathrm{~cm}$ thick. Lamella up to $2 \mathrm{~cm}$ thick in places, attenuating to curled margins. Oscules were not visible on the holotype. Cribriporal pore areas are widespread between parallel tangential tracts of oxeas; individual pores $80-160 \mu \mathrm{m}$ in diameter, on both sides of the lamella. Texture firm, compressible, flexible, granular and smooth to the touch. Colour in preservative tan.

\section{Skeleton}

Choanosome composed of huge swathes of long straight oxeas, radiating through the lamella, terminating below the surface (Fig. 6E). Contort oxeas are found in the stalk. Ectosome, relatively thick, packed with microxeas and perforated by ostia.

\section{Spicules}

Megascleres (Fig. 4B-C)

Oxeas with long fine attenuated tips, $1725(1150-2271) \times 16(8-22) \mu \mathrm{m}$; contort oxeas in the stalk, 1801(1095-2671) $\times 13(5-17) \mu \mathrm{m}$; short-shafted triaenes, relatively uncommon, rhabd straight, attenuating, 290(260-300) $\mu \mathrm{m}$, clads curved or acutely bent, occasionally with bifurcating tips, 232(200-250) $\mu \mathrm{m}$, cladome width 400-500 $\mu \mathrm{m}$ long.

Microscleres (Fig. 4D-F)

Microxeas, heavily microspined, sometimes faintly centrotylote and acutely centrally bent, sharp ended, abundant, $38(28-46) \times 3(2-4) \mu \mathrm{m}$; metaster- to amphiaster-like streptasters with long, microspined rays, rare, $8(5-12) \mu \mathrm{m}$ long; spirasters with dense, short rays, rare, 5-7 $\mu \mathrm{m}$ long.

\section{Distribution}

East of Snares Island Platform.

\section{Substrate, depth range and ecology}

Attached by a thick stalk to sediment covered rocky substrate, depth $125-213 \mathrm{~m}$. 


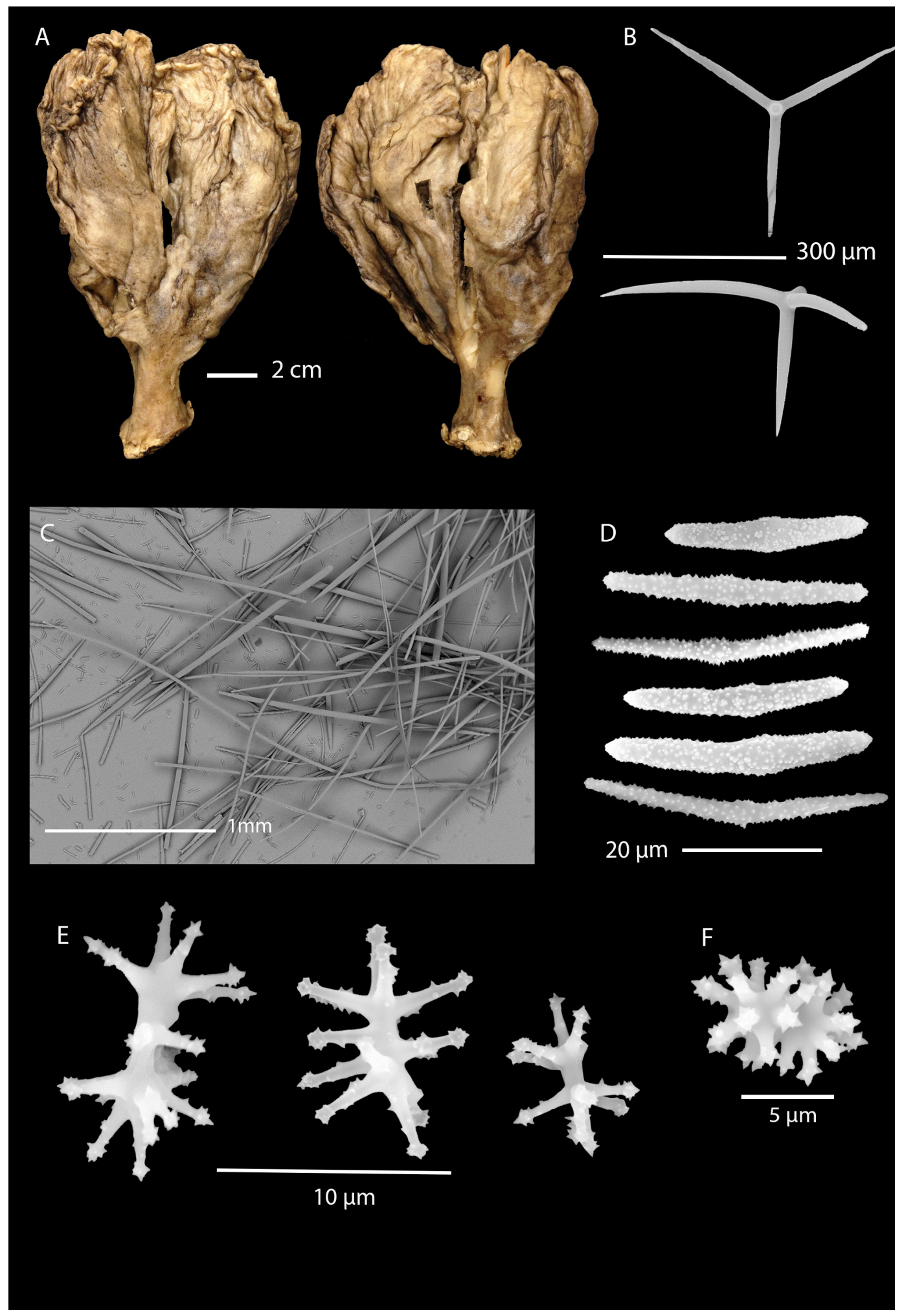

Fig. 4. Morphology, megascleres and microscleres of Poecillastra ducitriaena Kelly \& Cárdenas sp. nov. (NIWA 61944 leg., holotype). A. Preserved holotype showing stalked morphology (both sides). B. Shortshafted triaenes with curved clads and short rhabd. C. Sinuous and straight oxeas. D. Microspined microxeas, sometimes faintly centrotylote, sharp ended. E. Metaster- to amphiaster-like streptasters with long, microspined rays. F. Spirasters with dense, short rays. 


\section{DNA barcodes}

COI. Holotype (MK033626); 28 bp difference with the COI of L. strongylata; 24 bp difference with the COI of Poecillastra compressa (Bowerbank, 1866) (HM592675). 28S (C1-C2). Holotype (MK033144); 5 bp difference with the $28 \mathrm{~S}$ (C1-C2) of L. strongylata; 3 bp difference with the $28 \mathrm{~S}$ (C1-C2) of Poecillastra compressa (HM592757).

\section{Remarks}

This remarkable sponge was first identified as a third species of Lamellomorpha, as it appeared to have an almost identical form (stalked, multilamellar fan), a megasclere complement of straight and contort oxeas (more or less restricted to the stalk), small centrotylote microxeas, and metasters (albeit rare). Because the short-shafted triaenes were relatively uncommon, it was initially hypothesised that this was a species of Lamellomorpha with rudimentary triaenes that 'showed the way' to the true affinity of the genus with other triaene-bearing Tetractinellida. However, molecular sequencing consistently linked Poecillastra ducitriaena sp. nov. with other Poecillastra species (Fig. 7). Despite its consistency with two independent markers, we note that this grouping is not supported (bootstrap of 60 for COI, of 10 with 28S). This may be due to the absence of other subantarctic Poecillastra species in our sampling which Poecillastra ducitriaena sp. nov. may be closer to (P. Cárdenas, unpublished results).

Although not fully documented (Kelly et al. 2009), our knowledge of Poecillastra in the New Zealand region is reasonable and includes what we consider to be Poecillastra laminaris (Sollas, 1886) (Zeng et al. 2016) and Poecillastra schulzei (Sollas, 1886). While several undescribed species are known from the New Zealand EEZ, no specimens are known that contain the characteristic contort oxeas of Poecillastra ducitriaena sp. nov.

Poecillastra macquariensis Kelly \& Cárdenas sp. nov. urn:lsid:zoobank.org:act:78B12A37-93E0-4CA9-9317-81F835B112FE

Fig. 5

\section{Etymology}

Named for the type location of this species, the Macquarie Ridge.

\section{Type material}

\section{Holotype}

NEW ZEALAND • Subantarctic region of New Zealand, Seamount 5, Macquarie Ridge, NIWA Station TAN0803/48; $51.096^{\circ} \mathrm{S}, 161.976^{\circ} \mathrm{E}$; depth 462-524 m; 4 Apr. 2008; NIWA 52640 leg.; epibenthic sled; NIWA.

\section{Description}

Solid stalk of sponge of unknown morphology, $15 \mathrm{~mm}$ in diameter, $20 \mathrm{~mm}$ high, expanding on the broken, upper surface, sides of stalk sculpted, attachment base contains patches of substrate (Fig. 5A). Surface hispid and scratchy to the touch; texture firm, incompressible. Colour in preservative tan.

\section{Skeleton}

Stalk composed of huge swathes of contort oxeas and triaenes between which are abundant microscleres.

\section{Spicules}

Megascleres (Fig. 5D-E)

Abundant contort to sinuous oxeas (Fig. 5D) with slightly rounded tips, 3725(2125-5750) $\times 53(30-70$ ) $\mu \mathrm{m}$; medium-shafted triaenes (Fig. 5E), rhabd slightly curved, tapering to a sharp tip, 852(550-1225) $\mu \mathrm{m}$, 


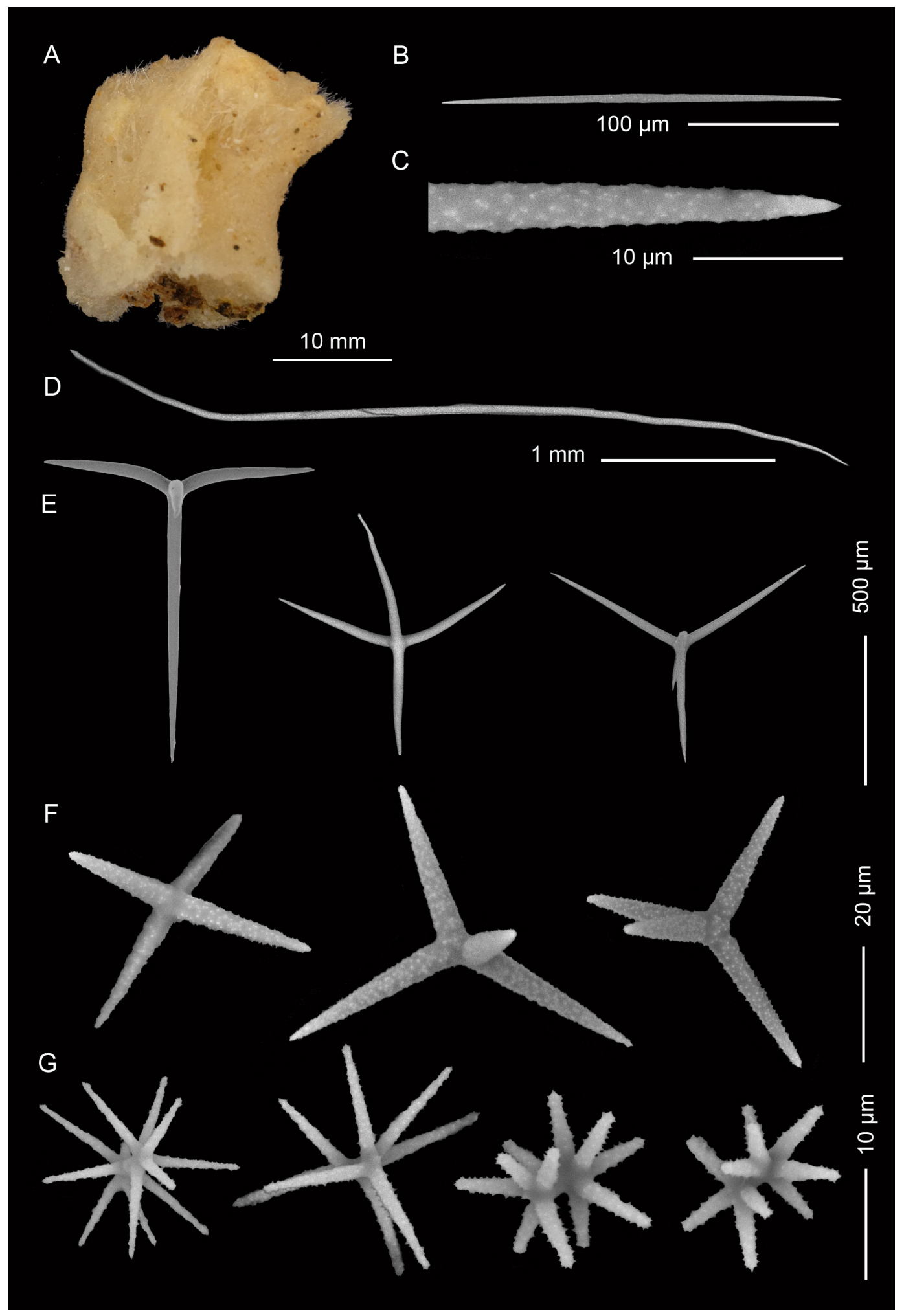

Fig. 5. Morphology, megascleres and microscleres of Poecillastra macquariensis Kelly \& Cárdenas sp. nov. (NIWA 52640 leg., holotype). A. Stalk, showing smooth attachment base with specks of remaining substrate, and broken edge of the upper part of the sponge. B. Microxeas. C. Detail of microxea showing roughened surface. D. Contort oxea of choanosome. E. Range of triaenes with medium to short shafts (calthrops). F. Plesiasters. G. Spiraster to metaster-like streptasters. 

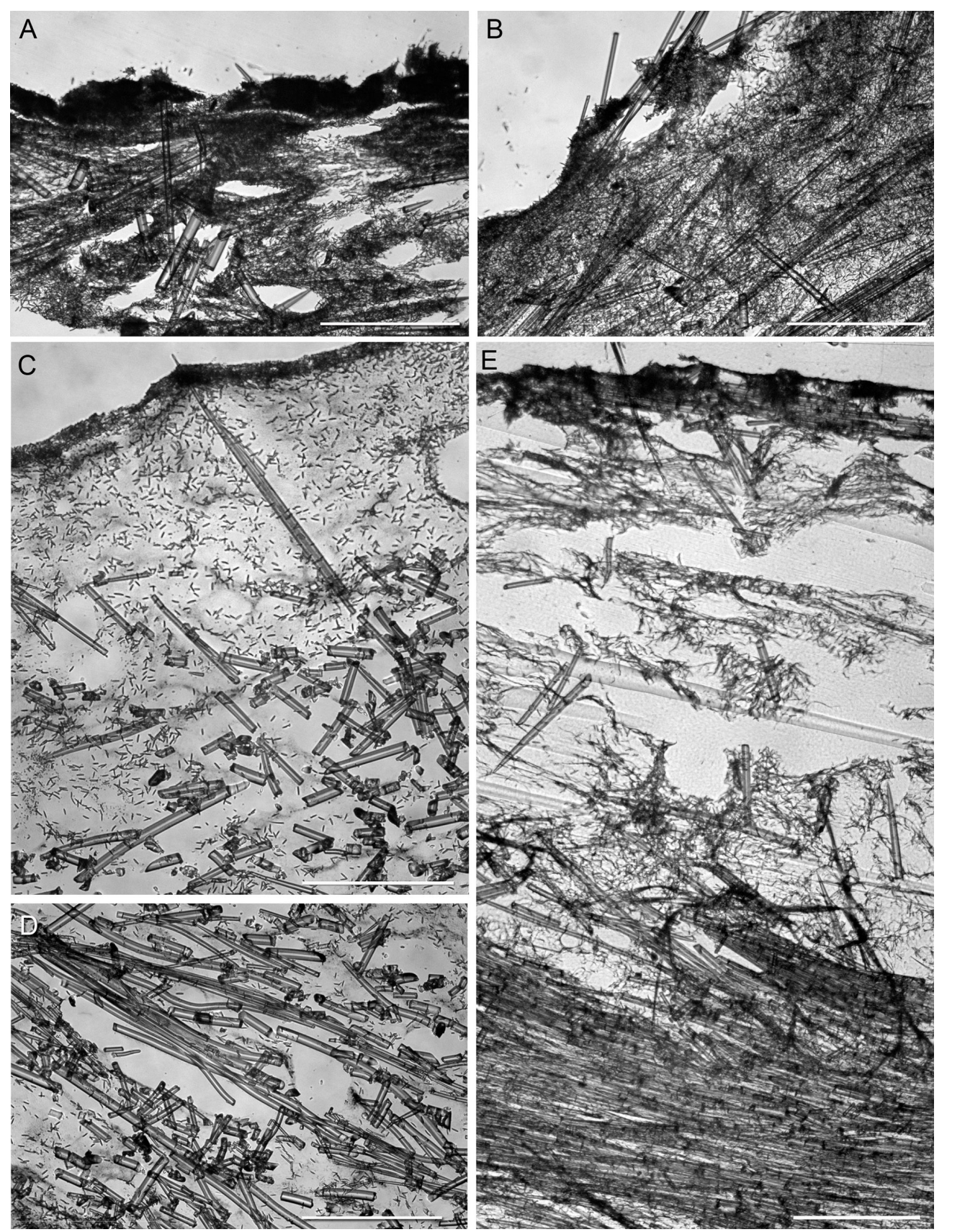

Fig. 6. Skeletal arrangement. A. Lamellomorpha australis Kelly \& Cárdenas sp. nov. showing dense, crustose ectosome packed with microrhabds and other microscleres, a rough megasclere bundle in the subectosome, emerging perpendicular to the surface, and the choanosome densely packed with microscleres (NIWA 89736 leg., holotype). B. L. australis sp. nov. showing the subectosome densely packed with microscleres, and megascleres radiating in the plane of the sponge body (NIWA 89717 leg.). C. L. strongylata Bergquist, 1968 showing a thin, fleshy ectosome packed with microrhabds and other microscleres, through which projects an 'extra-axial' tract of megascleres, traversing the subectosome and projecting through the surface (NIWA 93474 leg.). D. L. strongylata showing the 'axial' arrangement of contort strongyloxeas in the deep choanosome (NIWA 93474 leg.). E. Poecillastra ducitriaenea Kelly \& Cárdenas sp. nov. showing a densely packed, crustose ectosome through which subectosomal megascleres project, a relatively cavernous subectosomal region packed with microxeas, and in the deep choanosome, huge swathes of oxeas (NIWA 61944 leg., holotype). Scale bars $=500 \mu \mathrm{m}$. 
clads of slightly uneven length, slightly curved downwards, 578(450-680) $\mu \mathrm{m}$, overall cladome width, about $900-1360 \mu \mathrm{m}$ long, ranging to pseudocalthrops. Broken true oxeas are evident but unmeasurable.

Microscleres (Fig. 5B-C, F-G)

Microxeas (Fig. 5B-C), straight to slightly curved, roughened, abundant, 332(260-420) $\times 7(5-8) \mu \mathrm{m}$, $\mathrm{n}=20$; plesiasters (Fig. 5F), with 3 -5 microspined blunt-tipped rays, overall 67(50-100), ray length $37(25-60) \mu \mathrm{m}, \mathrm{n}=10$; metaster- to amphiaster- to spiraster-like streptasters (Fig. 5G), with long, microspined rays, abundant, 19(15-20) $\mu \mathrm{m}$ long.

\section{Distribution}

Macquarie Ridge.

\section{Substrate, depth range and ecology}

Attached to rock substrate; depth 462-524 m.

\section{Remarks}

The specimen is the attachment base of a sponge of unknown morphology, but it clearly differs from the holotype of Poecillastra ducitriaena sp. nov. in having a very hispid, crisp, scratchy surface, indicating a reduction of the ectosomal crust of microscleres, and the abundance of large megascleres. It is similar to Poecillastra ducitriaena sp. nov. in the possession of abundant contort oxeas in the stalk, but differs in the lack of straight oxeas in the stalk and the much larger dimensions of all the spicules: the contort oxeas are up to $2000 \mu \mathrm{m}$ longer, on average, in Poecillastra macquariensis sp. nov., and the triaenes are about double the size of those in Poecillastra ducitriaena sp. nov., and much more abundant, the microxeas are about ten times larger, and the sponge contains plesiasters, absent in Poecillastra ducitriaena sp. nov.

Because our knowledge of Poecillastra in the New Zealand region is reasonable (see above), we have made the decision to record and name this second Poecillastra species, despite our lack of information on the body shape, and because surface texture, spicule types and dimensions are so different from those of Poecillastra ducitriaena sp. nov.

\section{Discussion}

We were not successful in obtaining sequences from the holotype of L. strongylata (NIWA 356 leg.) but we obtained one Folmer COI sequence from non-type specimen NIWA $51172 \mathrm{leg}$. and one COI mini-barcode (130 bp) from non-type specimen NIWA 51267 leg., both from the same type locality, the Three Kings Islands. The $28 \mathrm{~S}$ fragment ( $\mathrm{C} 1-\mathrm{C} 2$ domains) was also obtained for the latter two specimens (369 bp each). We obtained one COI mini-barcode from the holotype of L. australis sp. nov. (NIWA 89736) but failed to amplify $28 \mathrm{~S}$ for $L$. australis sp. nov. We obtained the Folmer (661 bp) and the $28 \mathrm{~S}$ fragments (308 bp) from the holotype of Poecillastra ducitriaena sp. nov. (NIWA 61944 leg.).

In the COI tree (Fig. 7), the two species of Lamellomorpha, which have identical sequences (at least identical minibarcodes) were a sister group to Vulcanella Sollas, 1886; this grouping with Vulcanella was poorly supported (bootstrap of 61). Lamellomorpha + Vulcanella were sister to a poorly supported Poecillastra clade (bootstrap of 60), which included Poecillastra ducitriaena sp. nov. Despite these poorly supported nodes, the Vulcanellidae was a very well supported clade suggesting that Lamellomorpha is clearly part of this family. The 28S tree confirms the position of Lamellomorpha in the Vulcanellidae but with no true support. Vulcanella appeared paraphyletic (poorly supported), while the grouping of Lamellomorpha was uncertain with respect to Vulcanella or Poecillastra. This poor resolution may be due to the short sequences we obtained (308-369 bp), which are in fairly conserved domains of $28 \mathrm{~S}$ and so with few bp differences to differentiate species. 


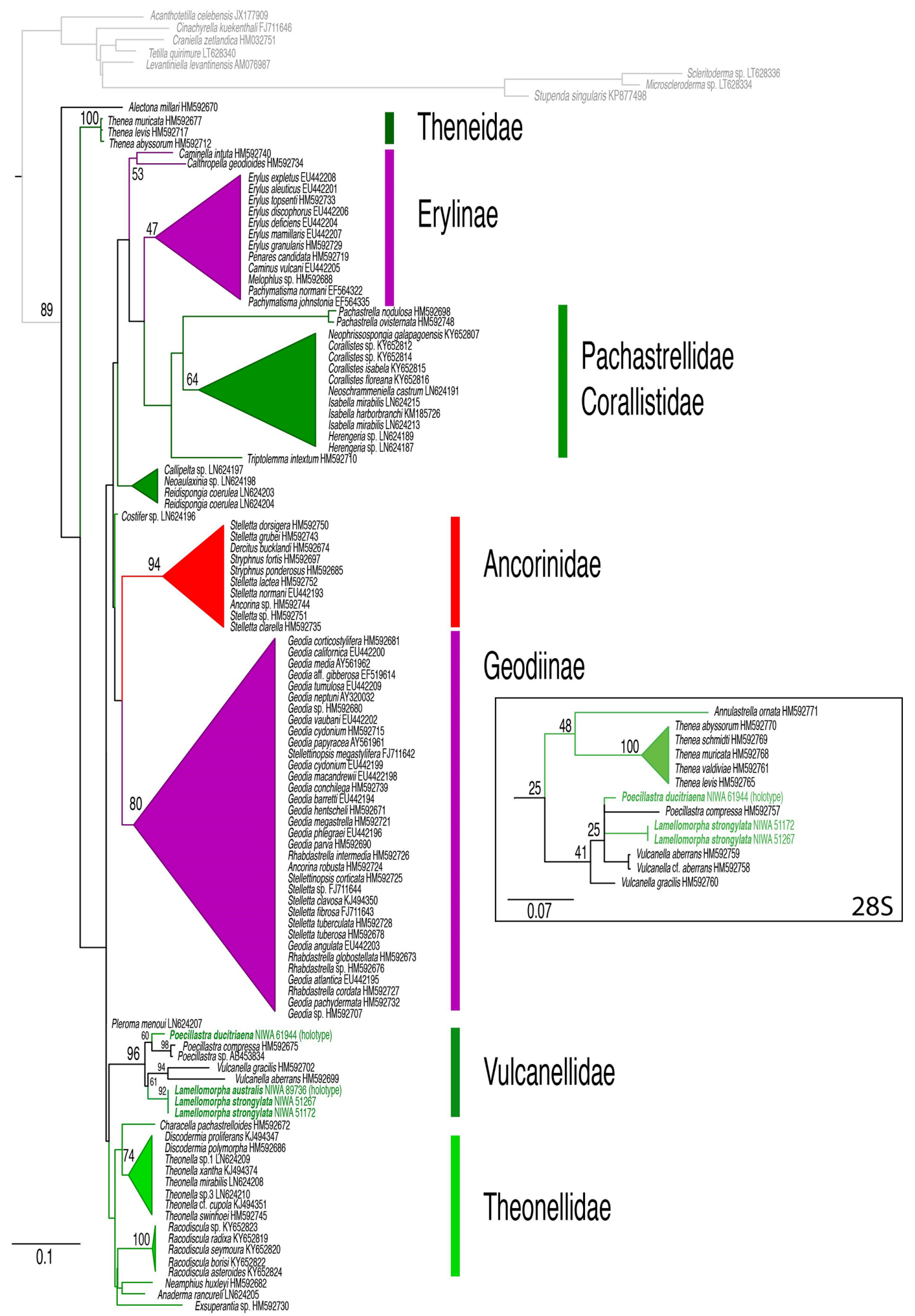

Fig. 7. Astrophorina COI and $28 \mathrm{~S}$ maximum likelihood (ML) trees reconstructed with RAxML under the generalized time-reversible Gamma (GTRGAMMA) model. ML bootstrap supports (100 bootstrap replicates). GenBank accession numbers are given after each taxon name. In green are the new sequences produced during this study. 
The grouping of Lamellomorpha with the Vulcanellidae suggested by the molecular markers is in accordance and supported by the morphological revision of this study. Indeed, the lamellate external morphology, the oscule/pore morphologies and distributions, as well as the skeleton organization in Poecillastra and Lamellomorpha are similar. Some spicules are also clearly homologous, such as the metasters to spirasters. The key discovery in this work is the confirmation that Lamellomorpha has integrity as a genus within the family Vulcanellidae, separate from Vulcanella and Poecillastra. This result generates new hypotheses about the evolution of spicules within the Vulcanellidae. The microrhabds in Lamellomorpha which earlier confused taxonomists, can now be considered as reduced Poecillastra/Vulcanella microxeas. Secondary losses of spicules have already been shown to be quite common in the Astrophorina (Cárdenas et al. 2011). Here, the short-shafted triaenes, which can be scarce (e.g., Poecillastra compressa) to quite rare (e.g., Poecillastra ducitriaena sp. nov.) in Poecillastra, would have been completely lost in Lamellomorpha. As for plesiasters (the largest streptaster category), they are absent in Lamellomorpha, as in some Poecillastra (e.g., Poecillastra ducitriaena sp. nov.) or Vulcanella (e.g., Vulcanella horrida (Schmidt, 1870)).

\section{Acknowledgements}

Specimens were provided by the NIWA Invertebrate Collection (NIC), and for material collected from the following research projects: Voyage KAH0606 — specimens were collected as part of a Ministry for Primary Industries funded voyage (NIWA project ENV2005-23), titled 'The Effects of Fishing on the Benthic Community Structure between North Cape and Cape Reinga'; Voyage TAN0803 - specimens were collected during the interdisciplinary New Zealand-Australian MacRidge 2 research voyage (TAN0803), the biological component of which was part of NIWA's research project, 'Seamounts: their importance to fisheries and marine ecosystems,' funded by the New Zealand Foundation for Research, Science and Technology, and CSIRO's Division of Marine and Atmospheric Research project, 'Biodiversity Voyages of Discovery,' funded by the CSIRO Wealth from Oceans Flagship; Voyage TRIP3072 - specimens collected under the Scientific Observer Program funded by the New Zealand Ministry for Primary Industries; Voyage TAN1105 - specimens were collected as part of the Biogenic Habitats on the Continental Shelf project (voyages TAN1105 \& TAN1108), funded by New Zealand Ministry of Fisheries (Biogenic Habitats: ZBD200801), New Zealand Foundation for Research, Science and Technology (CCM: CO1X0907), NIWA Capability Fund (CF111358) and Oceans Survey 20/20 RV Tangaroa days funded by Land Information New Zealand; NIWA Stn Z15944, collector CRRF: Coral Reef Research Foundation under contract to the US National Cancer Institute (N02-CM-77249).

We thank emeritus professors Murray Munro and John Blunt, Department of Chemistry, University of Canterbury, Christchurch, for the donation of their sponge vouchers to NIC, for their continued study. We also thank Dr Bruce Marshall, Museum of New Zealand Te Papa Tongarewa, Wellington, for the loan of specimens from their collections. We are grateful to John Rosser MA LTCL for his assistance with suggestions for new species names and advising on the correct form of the new taxon names. Satya Amirapu, Auckland University, carried out our histological work. PC received support from the European Union's Horizon 2020 research and innovation program through the SponGES project (grant agreement No. 679849). This document reflects only the authors' view and the Executive Agency for Small and Medium-sized Enterprises (EASME) is not responsible for any use that may be made of the information it contains. This research was funded by NIWA under Coasts and Oceans Research Programme Marine Biological Resources: Discovery and definition of the marine biota of New Zealand (2016/2017 to $2018 / 2019$ SCI). 
KELLY M. et al., Revision of Lamellomorpha

\section{References}

BergquistP.R. 1968. The MarineFauna of NewZealand:Porifera, Demospongiae, Part 1 (Tetractinomorpha and Lithistida). New Zealand Department of Scientific and Industrial Research Bulletin 188 (37): 1-105. [New Zealand Oceanographic Institute Memoir].

Bewley C.A., Holland N.D. \& Faulkner D.J. 1996. Two classes of metabolites from Theonella swinhoei are localized in distinct populations of bacterial symbionts. Experientia 52 (7): 716-722. https://doi.org/10.1007/BF01925581

Blunt J.W. \& Munro M.H.G. 2008. Lamellomorpha strongylata. In: Blunt J.W. \& Munro M.H.G. (eds) Dictionary of Marine Natural Products with CD-ROM: 285, 1798, 1854. Chapman \& Hall, CRC Press.

Buckingham J., Baggaley K.H., Roberts A.D. \& Szabó L.F. 2010. Lamellomorpha strongylata. In: Buckingham J., Baggaley K.H., Roberts A.D. \& Szabó L.F. (eds) Dictionary of Alkakoids with CD$R O M, 2^{\text {nd }}$ ed.: 349 . CRC Press, Taylor \& Francis Group.

Bycroft B.W. \& Payne D.J. 2014. Lamellomorpha strongylata. In: Bycroft B.W. \& Payne D.J. (eds) Dictionary of Antibiotics and Related Substances with CD-ROM, $2^{\text {nd }}$ ed.: 429, 1642. CRC Press, Taylor \& Francis Group.

Cárdenas P. \& Moore J. A. 2019. First records of Geodia demosponges from the New England Seamounts, an opportunity to test the use of DNA mini-barcodes on museum specimens. Marine Biodiversity 49 (1): 163-174. https://doi.org/10.1007/s12526-017-0775-3

Cárdenas P. \& Rapp H.T. 2012. A review of Norwegian streptaster-bearing Astrophorida (Porifera: Demospongiae: Tetractinellida), new records and a new species. Zootaxa 3253: 1-52.

Cárdenas P., Xavier J.R., Reveillaud J., Schander C. \& Rapp H.T. 2011. Molecular Phylogeny of the Astrophorida (Porifera, Demospongiae) Reveals an unexpected high level of spicule homoplasy. PLoS ONE 6 (4): e18318. https://doi.org/10.1371/journal.pone.0018318

Chombard C., Boury-Esnault N. \& Tillier S. 1998. Reassessment of homology of morphological characters in Tetractinellid sponges based on molecular data. Systematic Biology 47: 351-366. https://doi.org/10.1080/106351598260761

Cryer M., O’Shea S., Gordon D., Kelly M., Drury J., Morrison M., Hill A., Saunders H., Shankar U., Wilkinson M. \& Foster G. 2000. Distribution and structure of benthic invertebrate communities between North Cape and Cape Reinga. Final Research Report for Ministry of Fisheries Research Project ENV9805. Objectives 1-4: 1-154.

Dumdei E.J., Blunt J., Munro M.H.G. \& Pannell L.K. 1997. Isolation of Calyculins, Calyculinamides, and Swinholide $\mathrm{H}$ from the New Zealand deep-water marine sponge Lamellomorpha strongylata. Journal of Organic Chemistry 62 (8): 2636-2639. https://doi.org/10.1021/jo961745j

Folmer O., Black M., Hoeh W., Lutz R. \& Vrijenhoek R. 1994. DNA primers for amplification of mitochondrial cytochrome c oxidase subunit I from diverse metazoan invertebrates. Molecular Marine Biology and Biotechnology 3: 294-299.

Hickford S.J.H. 2007. Studies in the Chemistry of Marine Natural Products. PhD thesis, University of Canterbury, Christchurch. Available from https://ir.canterbury.ac.nz/handle/10092/1429 [accessed 19 Feb. 2019].

Hooper J.N.A. \& Maldonado M. 2002. Astrophorida Incertae sedis. In: Hooper J.N.A. \& Van Soest R.W.M. (eds) Systema Porifera. Guide to the Classification of Sponges 1: 165167. Kluwer Academic/ Plenum Publishers, New York, Boston, Dordrecht, London, Moscow. https://doi.org/10.1007/978-1-4615-0747-5_17 
Katoh K. \& Standley D.M. 2013. MAFFT multiple sequence alignment software version 7: improvements in performance and usability. Molecular Biology and Evolution 30 (4): 772-780. https://doi.org/10.1093/molbev/mst010

Kelly M. \& Cárdenas P. 2016. An unprecedented new genus and family of Tetractinellida (Porifera, Demospongiae) from New Zealand's Colville Ridge, with a new type of mitochondrial group I intron. Zoological Journal of the Linnean Society 177: 335-352. https://doi.org/10.1111/zoj.12365

Kelly M. \& Sim-Smith C. 2012. A review of Ancorina, Stryphnus, and Ecionemia (Demospongiae, Astrophorida, Ancorinidae), with descriptions of new species from New Zealand waters. Zootaxa 3480: $1-47$.

Kelly M., Edwards A.R., Wilkinson M.R., Álvarez B., Cook S. de C., Bergquist P.R., Buckeridge St.J., Campbell H.J., Reiswig H.M., Valentine C. \& Vacelet J. 2009. Phylum Porifera: Sponges. In: Gordon D.P. (ed.) New Zealand Inventory of Biodiversity: 1. Kingdom Animalia: Radiata, Lophotrochozoa, Deuterostomia: 23-46. Canterbury University Press, Christchurch.

Kelly-Borges M., Robinson E.V., Gunasekera S.P., Gunasekera M., Gulavita N.K. \& Pomponi S.A. 1994. Species differentiation in the marine sponge genus Discodermia (Demospongiae: Lithistida): the utility of ethanol extract profiles as species-specific chemotaxonomic markers. Biochemical Systematics and Ecology 22 (4): 353-365. https://doi.org/10.1016/0305-1978(94)90026-4

Larsson A. 2014. AliView: a fast and lightweight alignment viewer and editor for large datasets. Bioinformatics 30: 3276-3278. https://doi.org/10.1093/bioinformatics/btu531

Li S., Dumdei E.J., Blunt J.W., Munro M.H., Robinson W.T. \& Pannell L.K. 1998. Theonellapeptolide IIIe, a new cyclic peptolide from the New Zealand deep water sponge, Lamellomorpha strongylata. Journal of Natural Products 61 (6), 724-728. https://doi.org/10.1021/np970417r

Maldonado M. 2002. Family Pachastrellidae Carter, 1875. In: Hooper J.N.A. \& van Soest R.W.M. (eds) Systema Porifera. A Guide to the Classification of Sponges 1: 141-162. Kluwer Academic/Plenum Publishers, New York.

Miller M.A., Pfeiffer W. \& Schwartz T. 2010. Creating the CIPRES Science Gateway for inference of large phylogenetic trees. Proceedings of the Gateway Computing Environments Workshop (GCE), 14 Nov. 2010: 1-8. New Orleans, Los Angeles. https://doi.org/10.1109/GCE.2010.5676129

Morrow C. \& Cárdenas P. 2015. Proposal for a revised classification of the Demospongiae (Porifera). Frontiers in Zoology 12 (7): 1-27. https://doi.org/10.1186/s12983-015-0099-8

NABIS 2017. Lamellomorpha strongylata Bergquist, 1968. Annual distribution of a Spirits Bay invertebrate complex lineage. Internet mapping of New Zealand's marine environment, species distributions and fisheries management. Available from: www.nabis.govt.nz [accessed 2 Feb. 2019].

Ronquist F., Teslenko M., van der Mark P., Ayres D.L., Darling A., Höhna S., Larget B., Liu L., Suchard M.A. \& Huelsenbeck J.P. 2012. MrBayes 3.2: Efficient Bayesian Phylogenetic Inference and Model Choice Across a Large Model Space. Systematic Biology 61: 539-542. https://doi.org/10.1093/sysbio/sys029

SchusterA., Erpenbeck D., PiseraA., Hooper J.N.A., Bryce M., Fromont J. \& Wörheide G. 2015. Deceptive desmas: molecular phylogenetics suggests a new classification and uncovers convergent evolution of lithistid demosponges. PLoS ONE 10 (1): e116038. https://doi.org/10.1371/journal.pone.0116038

Schuster A., Cárdenas P., Pisera A., Pomponi S.A., Kelly M., Wörheide G. \& Erpenbeck D. 2018. Seven new deep-water Tetractinellida (Porifera: Demospongiae) from the Galápagos Islands morphological descriptions and DNA barcodes. Zoological Journal of the Linnaean Society 184: $273-$ 303. https://doi.org/10.1093/zoolinnean/zlx110 
Sollas W.J. 1888. Report on the Tetractinellida collected by H.M.S. Challenger, during the years $1873-$ 1876. Report on the Scientific Results of the Voyage of H.M.S. Challenger, 1873-1876. Zoology 25 (63): $1-458$.

Stamatakis A. 2014. RAxML Version 8: A tool for phylogenetic analysis and post-analysis of large phylogenies. Bioinformatics 30: 1312-1313. https://doi.org/10.1093/bioinformatics/btu033

Thacker R.W., Hill A.L., Hill M.S., Redmond N.E., Collins A.G., Morrow C.C., Spicer L., Carmack C.A., Zappe M.E., Pohlmann D., Hall C., Diaz M.C. \& Bangalore P.V. 2013. Nearly Complete 28S rRNA Gene Sequences Confirm New Hypotheses of Sponge Evolution. Integrative and Comparative Biology 53: 373-387. https://doi.org/10.1093/icb/ict071

Ueoka R.,UriaA.R., Reiter S., Mori T., Karbaum P., Peters E.E., Helfrich E.J.N., Morinaka B.I., Gugger M., Takeyama H., Matsunaga S. \& Piel J. 2015. Metabolic and evolutionary origin of actin-binding polyketides from diverse organisms. Nature Chemical Biology 11: 705-712. https://doi.org/10.1038/nchembio. 1870

Wakimoto T., Egami Y., Nakashima Y., Wakimoto Y., Mori T., Awakawa T., Ito T., Kenmoku H., Asakawa Y., Piel J. \& Abe I. 2014. Calyculin biogenesis from a pyrophosphate protoxin produced by a sponge symbiont. Nature Chemical Biology 10: 648-655. https://doi.org/10.1038/nchembio.1573

Wilson M.C., Mori T., Ruckert C., Uria A.R., Helf M.J., Takada K., Gernert C., Steffens U.A.E., Heycke N., Schmitt S., Rinke C., Helfrich E.J.N., Brachmann A.O., Gurgui C., Wakimoto T., Kracht M., Crusemann M., Hentschel U., Abe I., Matsunaga S., Kalinowski J., Takeyama H. \& Piel J. 2014. An environmental bacterial taxon with a large and distinct metabolic repertoire. Nature 506: 58-62. https://doi.org/10.1038/nature12959

Manuscript received: 23 October 2018

Manuscript accepted: 18 February 2019

Published on: 14 March 2019

Topic editor: Rudy CAM Jocque

Desk editor: Alejandro Quintanar

Printed versions of all papers are also deposited in the libraries of the institutes that are members of the EJT consortium: Muséum national d'Histoire naturelle, Paris, France; Meise Botanic Garden, Belgium; Royal Museum for Central Africa, Tervuren, Belgium; Royal Belgian Institute of Natural Sciences, Brussels, Belgium; Natural History Museum of Denmark, Copenhagen, Denmark; Naturalis Biodiversity Center, Leiden, the Netherlands; Museo Nacional de Ciencias Naturales-CSIC, Madrid, Spain; Real Jardín Botánico de Madrid CSIC, Madrid, Spain; Zoological Research Museum Alexander Koenig, Bonn, Germany. 